\title{
JEEE Xplort
}

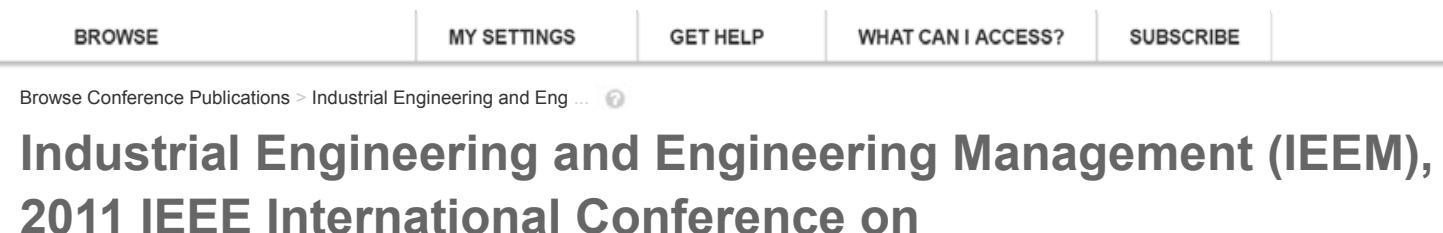

Date 6-9 Dec. 2011

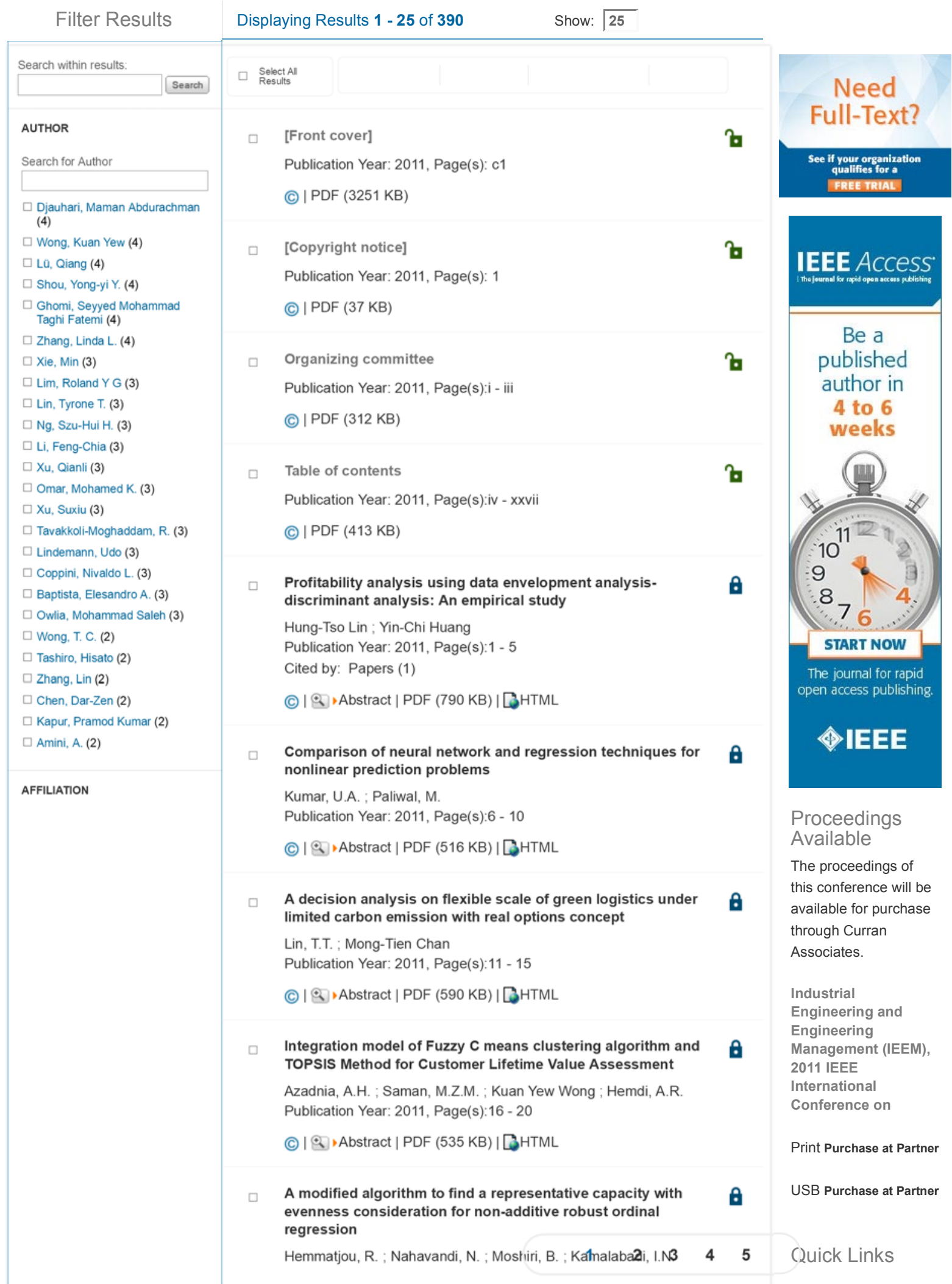


The IEEE International Conference on Industrial Engineering and Engineering Management

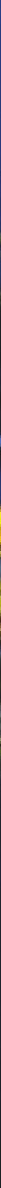

6 to 9 December 2011, Singapore Furama RiverFront Hotel

WWw.IEEM.org

oxmontele

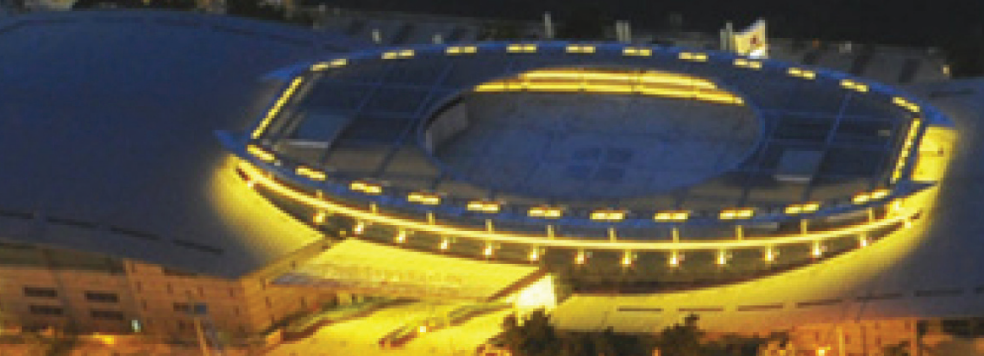

ax.
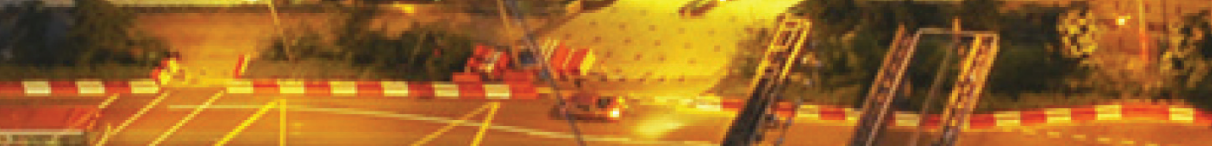

\section{ORGANIZED BY:}

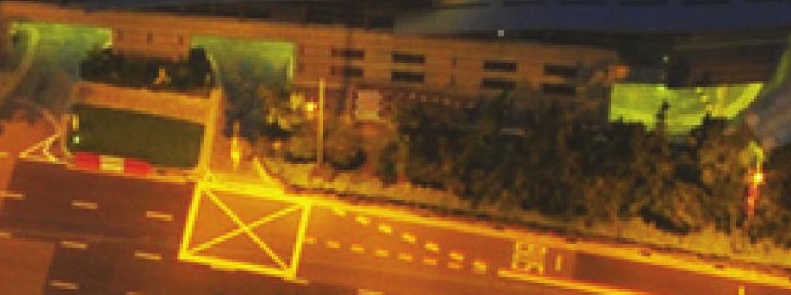


IEEE Catalog Number: CFP11IEI-ART

ISBN: 978-1-4577-0739-1

ISSN: $2157-362 \mathrm{X}$

Copyright and Reprint Permission: Abstracting is permitted with credit to the source. Libraries are permitted to photocopy beyond the limit of U.S. copyright law for private use of patrons those articles in this volume that carry a code at the bottom of the first page, provided the per-copy fee indicated in the code is paid through Copyright Clearance Center, 222 Rosewood Drive, Danvers, MA 01923. For other copying, reprint or republication permission, write to IEEE Copyrights Manager, IEEE Operations Center, 445 Hoes Lane, Piscataway, NJ 08854. All rights reserved. Copyright 2011 by IEEE. 
It is our great pleasure to welcome you to the 2011 IEEE International Conference on Industrial Engineering and Engineering Management. After having it in Hong Kong in 2009 and Macau in 2010, the IEEM conference is back in Singapore where it started.

As in the past years, we have received many submissions and each paper was sent to 3-4 reviewers. The rigorous review process has helped to maintain a high standard for this conference We would like to thank the technical program committee members and the author-reviewers for their help in the review process.

IEEM conference is truly an international event with about 50 countries/regions represented each time. We also have three prominent keynote speakers and a meet-the-editors panel for participants to discuss publication and research issues.

The conference is grateful to all authors for your interests and contributions. The supports from Singapore Management University, National University of Singapore and Nanyang Technological University are also greatly appreciated.

Finally, we wish all the participants a fruitful conference. To those overseas, we hope that you enjoy your stay in Singapore.

Arnoud de Meyer, General Chair, Singapore Management University

Min Xie, Organizing Committee Chair, City University of Hong Kong and National University of Singapore

Szu Hui Ng, Program Committee Chair, National University of Singapore

Roger Jiao, Program Committee Chair, Georgia Institute of Technology 


\section{Organizing Committee}

\section{General Chair}

Arnoud De Meyer,

Singapore Management University, Singapore

\section{Organizing Chair}

Min Xie,

City University of Hong Kong, Hong Kong and National University of Singapore, Singapore

\section{Program Chairs}

Roger Jiao,

Georgia Institute of Technology, USA

Szu Hui Ng,

National University of Singapore, Singapore

\section{Organizing Committee}

Anil Varma (Finance),

Singapore Polytechnic, Singapore

Carman Lee (Logistics),

Nanyang Technology University, Singapore

Songlin Chen (Publicity),

Nanyang Technology University, Singapore

Zhang Wu (Publication),

Nanyang Technology University, Singapore

Kah Hin Chai (Local Arrangement),

National University of Singapore, Singapore

\section{Members}

Nan Chen,

National University of Singapore, Singapore

\section{Siong Lin Ho,}

Ngee Ann Polytechnic, Singapore

\section{Zhaotong Lian,}

University of Macau, Macau

\section{Mei Qi,}

National University of Singapore, Singapore

Hongyi Sun,

City University of Hong Kong, Hong Kong

\section{Technical Program Committee}

Michel Aldanondo,

Univ Toulouse Mines Albi, France
Luciana Alencar,

Federal University of Pernambuco, Brazil

Teresa Alvarez,

University of Valladolid, Spain

Michel Anzanello,

Federal University of Rio Grande do Sul, Brazil

Ana Paula Barroso,

UNIDEMI, FCT-UNL, Portugal

\section{Arijit Bhattacharya,}

Dublin City University, Ireland

\section{Paul Chang,}

National Changhua University of Education, Taiwan

\section{Cheng-Wu Chen,}

National Kaohsiung Marine University, Taiwan

\section{Hung-Yi Chen,}

Chaoyang University of Technology, Taiwan

Mu-Chen Chen,

National Chiao Tung University, Taiwan

Shin-Guang Chen,

Tungnan University, Taiwan

\section{Hui-Ping Cheng,}

MingDao University, Taiwan

Kwai-Sang Chin,

City University of Hong Kong, China

Chuang-Chun Chiou,

Dayeh University, Taiwan

Tsan-Ming Choi,

The Hong Kong Polytechnic University, Hong Kong

Jui-Sheng Chou,

National Taiwan University of Science and Technology,

Taiwan

William Chung,

City University of Hong Kong, Hong Kong

Virgilio Cruz-Machado,

UNIDEMI, FCT-UNL, Portugal

Yves De Smet,

Université Libre de Bruxelles, Belgium

Uchenna Cyril Eze,

Monash University, Sunway Campus, Malaysia 
Laurent Geneste,

Univ Toulouse ENIT-LGP, France

Jiajun Gu,

Zhejiang Gongshang University, China

Rongxin Gu,

Tongji University, China

Guillermo Gutierrez,

Instituto Tecnologico de Morelia, Mexico

Md. Mamun Habib,

American International University-Bangladesh (AIUB),

Bangladesh

\section{Siana Halim,}

Petra Christian University, Indonesia

Takashi Hasuike,

Osaka University, Japan

William Ho,

Aston University, United Kingdom

Qingpei Hu,

Chinese Academy of Science, China

Chi-Cheng Huang,

Aletheia University, Taiwan

Chin-Yu Huang,

National Tsing Hua University, Taiwan

Shinji Inoue,

Tottori University, Japan

Mingzhou Jin,

Mississippi State University, United States

Yuya Kajikawa,

The University of Tokyo, Japan

Chompoonoot Kasemset,

Chiang Mai University, Thailand

Song-Kyoo Kim,

Samsung Electronics Co., Ltd, South Korea

Chien-Liang Kuo,

Chinese Culture University, Taiwan

Chil-Chyuan Kuo,

Ming Chi University of Technology, Taiwan

C.K. Kwong,

The Hong Kong Polytechnic University, China

Jun-Der Leu,

National Central University, Taiwan
Zhizhong Li,

Tsinghua University, China

Chen-Ju Lin,

Yuan Ze University, Taiwan

Chu-Ti Lin,

National Chiayi University, Taiwan

Tyrone T. Lin,

National Dong Hwa University, Taiwan

Mei-Chen Lo,

National United University, Taiwan

Huitian Lu,

South Dakota State University, United States

Virgínia Machado,

UNIDEMI, FCT-UNL, Portugal

Rammohan Maikala,

Liberty Mutual Research Institute for Safety, United States

Harekrishna Misra,

Institute of Rural Management Anand, India

Lars Moench,

University of Hagen, Germany

Zahra Mohaghegh,

University of Maryland, United States

Asadallah Najafi,

Islamic Azad University, Zanjan Branch, Iran

Mohamed k. Omar,

Notingham University Malaysia, Malaysia

Aditya Parida,

Luleå University of Technology, Sweden, Sweden

Taezoon Park,

Nanyang Technological University, Singapore

Jennifer Percival,

University of Ontario Institute of Technology, Canada

Alan Pilkington,

Royal Holloway, University of London, United Kingdom

Kit Fai Pun,

University of the West Indies, Trinidad and Tobago

Jerzy Stefan Respondek,

Silesian University of Technology, Poland

Prof. Suk-Chul Rim,

Ajou University, South Korea 
Mustafa Riza,

Eastern Mediterranean University, Turkey

Rashed Sahraeian,

Shahed University, Iran

Tomoko Saiki,

Tokyo Institute of Technology, Japan

Ilias Santouridis,

TEI of Larissa, Greece

Kiyoshi Sawada,

University of Marketing and Distribution Sciences, Japan

AHM Shamsuzzoha,

University of Vaasa, Finland

Ali Siadat,

Arts et Metiers ParisTech, France

Raj Siriram,

Dimension Data MEA, South Africa

Harm-Jan Steenhuis,

Eastern Washington University, United States

Pohsun Sung,

National Central University, Taiwan

Syafiie Syafiie,

University Putra Malaysia, Malaysia

Ramayah T.,

Universiti Sains Malaysia, Malaysia

Pei-Lee Teh,

Monash University, Malaysia

Purit Thanakijkasem,

King Mongkut's University of Technology Thonburi,

Thailand

Radha Ramanan Thiyagarajan,

National Institute of Technology Calicut, India

\section{Norbert Trautmann,}

University of Bern, Switzerland

Chih-Fong Tsai,

National Central University, Taiwan

Ming-Lang Tseng,

Lung Hwa University of Science and Technology,

Taiwan

\section{Yuan-Jye Tseng,}

Yuan Ze University, Taiwan

Enrico Vezzetti,

Politecnico di Torino, Italy
Junqiang Wang,

Northwestern Polytechnical University, China

Min Wang,

Chaoyang University of Technology, Taiwan

Shengyong Wang,

The University of Akron, United States

Yonggui Wang,

University of International Business and Economics, China

\section{Seng Fat Wong,}

University of Macau, Macau

Yongtao Xi,

Shanghai Maritime University, China

Yanqiu Xiao,

Zhengzhou University of Light Industry, China

Farouk Yalaoui,

Utt, France

Richard Yam,

City University of Hong Kong, Hong Kong

Hsu-Hao Yang,

National Chinyi University of Technology, Taiwan

Qz Yang,

Singapore Institute of Manufacturing Technology, Singapore

Min Yao,

Zhejiang University, China

Hsiu-Ping Yueh,

National Taiwan University, Taiwan

Suhaiza Zailani,

Universiti Sains Malaysia, Malaysia

Cai Wen Zhang,

School of Business, Sun Yat-sen University, China

Faping Zhang,

Beijing Institute of Technology, China

Linda Zhang,

IESEG School of Management, France

Xu Zhang,

Beijing Institute of Technology, China

Ahmed Zobaa,

Brunel University, United Kingdom 


\section{Table of Contents}

\section{Decision Analysis \& Methods (1)}

Profitability Analysis Using Data Envelopment Analysis-Discriminant Analysis: an Empirical Study 1 Hung-Tso LIN, Yin-Chi HUANG

Comparison of Neural Network and Regression Techniques for Nonlinear Prediction Problems Usha Anantha KUMAR, Mukta PALIWAL

A Decision Analysis on Flexible Scale of Green Logistics under Limited Carbon Emission with Real Options Concept Tyrone T. LIN, Mong-Tien CHAN

Integration Model of Fuzzy C Means Clustering Algorithm and TOPSIS Method for Customer Lifetime Value Assessment

Amir Hossein AZADNIA, Muhamad Zameri MAT SAMAN, Kuan Yew WONG, Abdul Rahman HEMDI

A Modified Algorithm to Find a Representative Capacity with Evenness Consideration for Nonadditive Robust Ordinal Regression Roghayeh HEMMATJOU, Nasim NAHAVANDI, Behzad MOSHIRI, I. NAKHAI

Established the Evaluation Structure of the Investment Benefit of the "Doubling Tourist Arrivals Plan" in Taiwan

Huey-hsi LO, Pei-cheng WEN

\section{Decision Analysis \& Methods (2)}

Analyzing Newsvendor Problems by One-Shot Decision Approaches with Considering Regret Peijun GUO, Yating YANG

Simplification of Decision Making Matrix in Fuzzy Multiple Attribute Decision Making Zhi PEI, Li ZHENG

A Petri Net Approach to Resource Allocation in Brand Management Systems Hongwei LIAO, Min LU

Optimal Determination of Simulated Annealing Parameters using TOPSIS Fateme FOTUHI

Merger and Acquisition Decisions Analysis with Sustainability Operation Concept Tyrone T. LIN, Yi-Shun HUANG

Simulation-Based Operational Decision Analysis at Decoupling Point in MTS-MTO System Feng Yu WANG, Laura Xiao Xia XU, Ronald LIM, E.W. LEE, Michal ZARZYCKI

\section{Decision Analysis \& Methods (3)}

Applying Green Goodwill for Project Management on Green Economics Concept Tyrone T. LIN, Wei-Cheng WU

A Fuzzy-based Integrated Framework for Monitoring Stochastic Demand in a Supply Chain 66 Environment Henry LAU, Premaratne SAMARANAYAKE, Dilupa NAKANDALA 
A Multicriteria Decision Model for Managing Business Processes

Reducing Violence: A Proposal Based on Multicriteria SMARTS Method Andre GURGEL, Caroline MOTA, Dario ALOISE

Selection and Ranking of Improvement Approaches in Construction Companies: SMARTS Method Renata Maciel de MELO, Denise MEDEIROS, Adiel ALMEIDA

Innovative Support of Creation by Analogy-based Searching of Potential Needs Takayuki SUZUKI, Taro TEZUKA, Atsushi AOYAMA, Fuminori KIMURA, Akira MAEDA

Insurance Pricing, Reinsurance and Investment Decision Based on the Mutual Benefit of the Insurer and the Customer

Hong MAO, Krzysztof M. OSTASZEWSKI

Enhancing Tool Availability in the Forging Industry by Adjusting PPC and Tool Maintenance

96 Anis SELAOUTI, Sven BAUMGARTEN, Jens-Michael POTTHAST, Rouven NICKEL

\section{Operations Research (1)}

Robust Optimization for Resource-constrained Project Scheduling with Uncertain Activity Durations Roel LEUS, Christian ARTIGUES, Fabrice TALLA NOBIBON

EPSO for Solving Non-oriented Two-dimensional Bin Packing Problem Mohamed K. OMAR, Kumaran RAMAKRISHNAN

Equivalent Relationships of Problem Formulations Optimizing Forecast Accuracy Xue-Ming YUAN, Wee Meng YEO, Joyce M.W. LOW

Multi-heuristics Based Genetic Algorithm for Solving Maritime Inventory Routing Problem Nurhadi SISWANTO, Daryl ESSAM, Ruhul SARKER

A Heuristic Algorithm for Substrates Testing in MCM Keisuke MURAKAMI

Nash Equilibruim Retail Prices in a Linear Duopoly Market Tomoki HAMAGUCHI, Koichi NAKADE

Cross Docking Scheduling with Delivery Time Window and Temporary Storage Dwi AGUSTINA, Carman Ka Man LEE, Rajesh PIPLANI

\section{Operations Research (2)}

A Stochastic Formulation of Successive Software Releases with Faults Severity Ompal SINGH, Pramod Kumar KAPUR, Adarsh ANAND

Capacitated Hub Location Problems with Waiting Time at Hubs Arsham ATASHI, Mostafa ABEDZADEH

Evaluation on Operation Management of Cascade Hydropower Stations Y. ZHENG, X.D. FU, Jia Hua WEI, Xiang LI

A Review of Data Envelopment Analysis Models for Handling Data Variations Chuen Tse KUAH, Kuan Yew WONG 


\section{Operations Research (3)}

A Hospital Admission Planning Model for Emergency and Elective Patients Under Stochastic

Resource Requirements and No-shows

Phongchai JITTAMAI, Thirapan KANGWANSURA

Multi-processor Job Shop Scheduling with Due Windows

Rong-Hwa HUANG, Shun-Chi YU

Spreadsheet Approach for Solving Complex Flowshop Scheduling Problems

A Pseudo-efficient Frontier Method for Solving Two-Phase Packing Problems David RAZ, Arik SADEH

Moral Hazard Resolved in Communication for S4n-Logic - Acyclic Communication Network Case Takashi MATSUHISA

Optimization of Multi Periods Inventory Routing Problem Model with Time Varying Demand Noor Hasnah MOIN

A Math-heuristic Approach for Integrated Resource Scheduling in a Maritime Logistics Facility Hua Xing CHEN, Hoong Chuin LAU

A Tabu Search Algorithm for Integrated Inventory and Vehicle Routing Problem in One Depot and

Multicustomers Distribution System

Anchalee SUPITHAK

\section{Supply Chain Management (1)}

Effective Design of the Construction Supply Chain: A Case of Small Buildings in Thailand Sataporn AMORNSAWADWATANA

Simply Structured Policies for a Dynamic Pricing Problem with Constant Price Elasticity Demand Chia-Shin CHUNG, James FLYNN

Governance Mode in Reverse Logistics: a Research Framework Qing LU, Mark GOH, Robert De SOUZA

Developing an Improved Particle Swarm Optimization Algorithm for Solving the Inventory Routing Problem with Direct Shipment I. NAKHAI, Seyed Hessameddin ZEGORDI, Ali HOSSEIN MIRZAEI

Risks Assessment of Lower Tier Suppliers Using Operational Reliabilities and Product Availabilities Gopal AGARWAL, Piyush SINGHAL, Murari LAIMITTAL

EOQ Model Development for Perishable Items under Stock Dependent Demand and Time Dependent Partial Backlogging by Using Intelligent Packaging Narges KHANLARZADE, I. NAKHAI, B. YOUSEFI

A Study on Lean Supply Chain Performance Measures of SMEs in the Automotive Industry 


\section{Supply Chain Management (2)}

An Exploratory Research on Educational Supply Chain Management

Production and Distribution Planning Model for Hinterland Supply Chain

Shi Tao ZHAO, Xue-Ming YUAN, Shih Fu LING

The Application of Vendor Managed Inventory in the Supply Chain Inventory Model with

Probabilistic Demand

Yosi Agustina HIDAYAT, Ika DEEFI ANNA, Arlene KHRISNADEWI

A Logistics Execution Method for the Regional Distribution Center

Yuan-Kuei HUANG, Wei-Jun LU, Jun-Der LEU

Research on Measuring Method of Supply Chain Resilience Based on Biological Cell Elasticity

Theory

Ying SHUAI, Xinping WANG, Lindu ZHAO

Critical Success Factors of Total Productive Maintenance Implementation: A Review Kam-Choi NG, Gerald Guan Gan GOH, Uchenna Cyril EZE

\section{Supply Chain Management (3)}

Designing the Optimal Strategies for Supply Chain Financing under Warehouse Receipt Pledging

with Credit Line

Nina YAN, Tian TIAN

A Framework for Integrated Assessment of Sustainable Supply Chain Management

Farzad DEHGHANIAN, Saeed MANSOOR, Mahboobeh NAZARI

A Multiobjective Evolutionary Approach for Integration of Location-Inventory and Vendor Selection

Decisions

Chia-Lin HSIEH

Selection of Distribution Centers with the Time Value of Money and the Loyal Customer Effect Alireza AMINI, Reza TAVAKKOLI-MOGHADDAM, Armand BABOLI

Coffee Waste Management. A Case Study

Virginia MACHADO, Ana Paula BARROSO, Carolina SANTOS, Virgilio CRUZ MACHADO

A Buffer Stock Model to Ensure Price Stabilization and Availability of Seasonal Staple Food by

Empowering Producer Using Warehouse Receipt System

Wahyudi SUTOPO, Senator NUR BAHAGIA, Andi CAKRAVASTIA, T.M.A. ARISAMADHI

Conceptual Model for Information Systems of Sustainable Supply Chain Management

Majid AARABI, Muhamad Zameri MAT SAMAN, Mohammad Reza KHOEI, Kuan Yew WONG, Hooshang M. BEHESHTI, Norhayati ZAKUAN

Using an Artificial Neural Network and a Mathematical Model for Sugarcane Harvesting Scheduling Surached THUANKAEWSING, Supachai PATHUMNAKUL, Kullapapruk PIEWTHONGNGAM

\section{Production Planning \& Control (1)}

Optimum Quantities of Make and Buy in Multi-Item Manufacturing Firms with Restriction in 
Study and Application of Scheduling Method for Just-in-time Production in Flexible Job Shops

Wei WENG, Shigeru FUJIMURA

Order Selection of Processed Chicken under Production Capacity Constraints

Pachara CHATAVITHEE, Kullapapruk PIEWTHONGNGAM, Supachai PATHUMNAKUL

Clustering Variables Selection in Mass Customized Scenarios Affected by Workers' Learning Michel ANZANELLO, Flavio FOGLIATTO

Interactive Online Process Management and Quality Control for Cross-Sited Production Process

Chains

Peter BECKER, Robert SCHMITT

Periodic Virtual Cell Manufacturing (P-VCM) - Concept, Design, and Operation

Jannes SLOMP, Dimitry KRUSHINSKY, Rahul CAPRIHAN

A Novel Virtual Design Platform for Product Innovation Through Customer Involvement

Xingyu CHEN, Chun-Hsien CHEN, Kah Fai LEONG

\section{Production Planning \& Control (2)}

Adaptive Scheduling by Means of Product-specific Emergence Data Gunther REINHART, Florian GEIGER

A Worker Assignment for Machine Cluster in the Manufacturing Cell Suksan PROMBANPONG, Waraporn SEENPIPAT

Optimal Production Policy of Production System with Inventory-level-dependent Demand in

Segmented Market

Yogender SINGH, Kuldeep CHAUDHARY, P.C. JHA

Heuristic Decomposition and LP-based Scheduling in Make-and-Pack Production

Philipp BAUMANN, Norbert TRAUTMANN

Robust Optimization Model for Fan Coil Production Planning under Supply Uncertainty Jamshid NAZEMI, Roja ZAKERI

An Application of Network Topology to Understand The Signal in Process Variability: A Case Study in Petrochemical Industry

Shamshuritawati SHARIF, Maman DJAUHARI

\section{Human Factors}

Monitoring and Classifying Evidence-Based Workload for Profiling Manual Handling Occupations Jan Pieter CLARYS, Jonathan TRESIGNIE, Aldo SCAFOGLIERI, Erik CATTRYSSE

Measurement of Handgrip Force of the Dominant Hand at Pre-selected Force Levels for Males Kai-Way $L I$

Lumbosacral Bending Moment Assessment and Parameter Optimization Using Taguchi Design during Lifting Task in a Steel Rolling Mill Sarbjeet SINGH, Sunand KUMAR

A Perspective on Human Factors Contributing to Quality Requirements: a Cross-case Analysis Annlize MARNEWICK, H.C. PRETORIUS, Leon PRETORIUS

Occupational Stress, Knowledge Sharing and GSD Communication Barriers as Predictors of Software Engineer's Creativity

Aamir AMIN, Shuib Bin BASRI, Mohd Fadzil HASSAN, Mubashir REHMAN 
Miners' Tacit Knowledge: A Unique Resource for Developing Human-oriented Lean Mining Culture

in Deep Mines

Mohammed Aminu SANDA, Jan JOHANSSON, Bo JOHANSSON

Identifying the Meaning of Information Signs in Traffic Facilities

405

Hsien-Yu TSENG, Bor-Shong LIU

Analysis of Design and Purchase Decision of Central Dust Collection System Yeasin BHUIYAN, A.l. KHAN

\section{Global Manufacturing and Management}

Role of Knowledge Management in World Class Manufacturing: an Empirical Investigation Abhijeet DIGALWAR, Kuldip Singh SANGWAN

Statistical Quality Control Measurement on Furniture Manufacturer LAURENCE, Christine PUTERI UTAMA, Jessica HANAFI

The Influence of Geothermal Environment to the Quality of Porcelain Insulator: A Correlation Analysis

Syahidah YUSOFF, Maman DJAUHARI

Learning Organisation in New Zealand and Malaysian Manufacturing Companies Affandi MOHD-ZAINAL, Jane GOODYER, Nigel GRIGG, Jafri Mohd ROHANI

Integration of Production and Supply Chain Strategic Planning for Renewable Resources under Sustainability Considerations: Teakwood Case Study Bobby KURNIAWAN, Muhammad HISJAM, Wahyudi SUTOPO

On Work Performance for the Labor-intensive Manufacturing Shin-Guang CHEN

\section{Engineering Education and Training}

In House Industrial Training for Mechanical Engineering Students: a Multidisciplinary Approach S.K. LI, KK LAU, Vincent LI

RFID-Aided Manufacturing Training System and Localization Seng Fat WONG, W. I. HO, Zhixin YANG, C. T. KWOK

Students' Experiences in Different Forms of Support during Doctoral Studies Katja LAHENIUS, Salla MAATTA

Educational Game Concept for the Transfer of Results from the Transdisciplinary Research to the New Scientific Generation Florian G. H. BEHNCKE, Moritz KING, Udo LINDEMANN

Quantitative Analysis of International Mobility of Robotics Researchers and Characteristics of Domestic Robotics Research Takao FURUKAWA, Nobuyuki SHIRAKAWA, Kumi OKUWADA, Kazuya SASAKI

Green Design Principles and Trends of Using Them among Bangladeshi Consumer Goods

Manufacturers

Md. Shahriar Jahan HOSSAIN, Nafis AHMAD 


\section{Intelligent Systems}

Evolutionary-Based Support Vector Machine R. J. KUO, C. M. CHEN

The Effectiveness of Hybrid Negative Correlation Learning in Evolutionary Algorithm for

Combinatorial Optimization Problems

Ronnachai SIROVETNUKUL, Parames CHUTIMA, Warin WATTANAPORNPROM, Prabhas

CHONGSTITVATANA

A New Guillotine Placement Heuristic Combined with an Improved Genetic Algorithm for the

Orthogonal Cutting-Stock Problem

Slimane ABOU MSABAH, Ahmed Riadh BABA-ALI

Intelligent System for Wind Generating Plant Yoko AMANO

Collaborative and Non-Collaborative Dynamic Path Prediction Algorithm for Mobile Agents

Collision Detection with Dynamic Obstacles in a Two-dimensional Space

Elmir BABOVIC

Component-Integrated Sensors and Communication for Gentelligent Devices

Ludger OVERMEYER, Lutz RISSING, Marc C. WURZ, Michael DUMKE, Stefan FRANKE, Tim GRIESBACH,

Alexander BELSKI

Data Mining Application for Customer Segmentation Based on Loyalty: An Iranian Food Industry

Case Study

Ali HAJIHA, Reza RADFAR, Samira Sarafi MALAYERI

Technology and Knowledge Sharing Strategy in Systems Engineering Practice performed by

Indonesian Expatriate Engineers

Ika WINDIARTI, Timothy FERRIS, Matthew BERRYMAN

\section{Poster Session 1}

An Integrated Multi Agent Based Model to Find the Most Agile Supplier Hoda GHAHREMANLOO, Mohamad Jafar TAROKH

Measuring Supply Chain of Packed Milk from Consumer Perspective in Pakistan Fariza KAMRAN, Osman BABAR, Muhammad ASIM

Impact of Product Design Decisions within Product Development on the Supplier Selection Process at the Automotive Industry Florian G. H. BEHNCKE, Katrin ABELE, Udo LINDEMANN

A Measurement Model for Collaboration between Suppliers and Manufacturers Pingyuan ZOU, Hao ZHANG

An Optimization Model for Global Supplier Selection Ramzi HAMMAMI

Service Supply Chain Practices from the Perspective of Malaysian Tourism Industry T.K. HONG, Suhaiza ZAILANI

Optimal Selection of Location for Distributed Generations to Ensure a Competitive Advantage Using Fuzzy Analytical Network Process Mahdiyeh MONTAZERI, Mohammad Saleh OWLIA, A MOGHIMI, Mohamad KAMALZADEH 
A Self-Crossover Genetic Algorithm for Job Shop Scheduling Problem

Shiwang HOU, Yongjiang LIU, Haijun WEN, Yuepeng CHEN

A Solution to the Capacitated Lot Sizing Problem

Zhicong ZHANG, Weiping WANG, Shouyan ZHONG, Kaishun HU

Non-cooperative Game Decision for Capacity Evaluation under Output Demand Uncertainty Ting YANG, Dinghua ZHANG, Bing CHEN, Shan LI

Losses Caused by the Presetting of Tools by the Manual Method Milton Vieira JUNIOR, Jose Martinele A. SILVA, Ivan CORRER, Nivaldo L. COPPINI, Elesandro A. BAPTISTA

Feature Fatigue Analysis Based on Behavioral Decision Making Mingxing $W U$, Liya $W A N G$

Value Stream Mapping Simulation Using ProModel Software Nivaldo L. COPPINI, Luiz C. BEKESAS, Elesandro A. BAPTISTA, Milton Vieira JUNIOR, Wagner C. LUCATO

Simulation for Implementing RFID-EPC in Reverse Supply Chain Based on Consumer Market Qiaolun GU, Tiegang GAO

The Use of Artificial Neural Network (ANN) for Modeling of Diesel Contaminated Soil Remediation by Composting Process

Mehrdad KHAMFOROUSH, M-Javad RAHI, Tahmas HATAMI, Kourosh RAHIMZADE

Integrated Development of Space Systems - Design for AIT - Design for Assembly, Integration and Testing of Satellites - D4AIT Adalberto Coelho SILVA, Geilson LOUREIRO

Using Structural Complexity Management for Design Process Driven Modularization Harrys DANIILIDIS, David HELLENBRAND, Wolfgang BAUER, Udo LINDEMANN

Study on Dynamical Properties and Simulation of a Four- Dimensional Nonlinear Discrete Dynamics Jing PENG, Zehua MIAO, Luoping ZHENG

Organizational E-Readiness Impact on E-Procurement Implementation Naseebullah LANGOVE, Shuib Bin BASRI, P. D. D. DOMINIC, Muhammad JEHANGIR

Technological Economic Study for Ocean Energy Development in China Tianqi WANG, Peng YUAN

Profit Generation in a Machining Service Provider - Optimization Combining Theory of Constraints and Contribution Margin Concept

Elesandro A. BAPTISTA, Wagner C. LUCATO, Nivaldo L. COPPINI, Milton Vieira JUNIOR, Luiz C. BEKESAS

Understanding Project Success: The Four-Level Project Success Framework Eskander HOWSAWI, David EAGER, Ravindra BAGIA

Probabilistic Sustainable Design Using Multiobjective Optimization Model Jui-Sheng CHOU, Thanh-Son LE

The Role of Time, Cost and Quality in Project Management Nurul Izah ANUAR, Poh Kiat NG

A Study of Measuring the Impact of Employee Perception on Business-IT Alignment via Neural

Network

T. C. WONG, Shing-Chung NGAN, Felix T. S. CHAN, Alain Y. L. CHONG 
New Insight into Technology Licensing Strategy and Innovation Performance: Evidence from

Chinese Latecomers in High-tech Industries

Yang Yang ZHAO, P.K. WONG, A. M. SUBRAMANIAN, C. C. HANG

Functional Semantic Retrieval for Effects Knowledge Base Hongtao WU, Jinling ZHANG, Jianhong MA, Runhua TAN

Constructing a Dynamic Evaluation Model for Corporate Diversification — The Thin-film Solar Cell Chang-Lin YANG, Rong-Hwa HUANG

A Study of Inter-firm Network and Knowledge Integration Impact Mechanism on Absorptive Capacity Zhigang FAN, Shuai GENG, Xiaoying PENG

Adoption of Hierarchical Structure for Web Document Analysis in Knowledge Management System Rozlini MOHAMED, Junzo WATADA

Activities and Problems in New Product Development Process in the Networking Industry - A Case of Different Business Models Min-Sun WUANG, Shu-Min CHIANG

A Case Study on the Importance of Knowledge Management in Creative Product Development Poh Kiat NG, Nurul Izah ANUAR

Improving a Model for New Service Development Alireza SHEIKHZADEH, Hamed HEIDARI

HSR Buying Behavior Modeling-Taiwan High Speed Railway Case Hsiao-min CHUANG, Chihpeng CHU, Yu-tzeng LIN

An Approach of Quality Management in the Small Business Environment of South Africa Bingwen YAN, Li ZHANG

\section{Decision Analysis \& Methods (4)}

Genetic Algorithm for the Project Scheduling Problem with Fuzzy Time Parameters Yilun HUANG, Yongyi SHOU, Linda ZHANG

Detection and Improvement of Deficiencies and Failures in Public- Transportation Networks using Agent-Enhanced Distribution Data Mining Eugene LEVNER, Avishai CEDER, Amir ELALOUF, Yuval HADAS, Dvir SHABTAY

Forecasting the Exchange Rate between ASEAN Currencies and USD Tien-Chin WANG, Su-Hui KUO, Hui-Chen CHEN

Pricing Annuity Insurance Integrating Mortality Improvement Risk, Interest Rate Risk, Insolvency Risk and Insurance Demand Hong MAO, Krzysztof M. OSTASZEWSKI, Yuling WANG

Possibilistic Programming Decision Making in Modality Perspective Arbaiy NUREIZE, Junzo WATADA

Towards a Lifecycle-oriented Planning of a Platform Portfolio Sebastian A. SCHENKL, Robert ORAWSKI, Fatos ELEZI, Udo LINDEMANN 


\section{Decision Analysis \& Methods (5)}

About Combined Non-Expansive and Potentially Expansive Properties of a Class of Self-Maps in

Metric Spaces

Manuel DE LA SEN

A Preliminary Study About the Application of Multicriteria Decision Aid to the Evaluation of the

Road Projects' Performance on Sustainable Safety

Renaud SARRAZIN, Yves DE SMET

Exploration of Product Value - Characteristic Relationship: Partial Least Squares Path Modeling for

Product Design and Development

Chathura WITHANAGE, Taezoon PARK, Truong Ton Hien DUC, Hae-Jin CHOI

Comparison between Regression Analysis and Artificial Neural Network in Project Selection. Oludolapo OLANREWAJU, Adisa JIMOH, Pulek KHOLOPANE

Application of TOPSIS Method for Evaluating the Temporal Dimensions of Marand City in Urban Design

Maliheh HASHEMI, Mehdi AMIRI-AREF

Production and Raw Material Ordering Management for a Manufacturing Supply Chain with

Uncertainties

Wei XU, Dongping SONG, Michael ROE

Features Selection Approaches Combined with Effective Classifiers in Credit Scoring Chia-Ching LIN, Chin-Chih CHANG, Feng-Chia LI, Tzu-Chin CHAO

\section{Manufacturing Systems (1)}

Integrated Optimisation of Facilities Layout and Material Handling System

Model of Spine Configuration Assembly Line Design for a Product Family Dida DAMAYANTI, Isa Setiasyah TOHA

Multi-objective Assembly Line Balancing Problem with Bounded Processing Times, Learning Effect, and Sequence-dependent Setup Times Nima HAMTA, Seyyed Mohammad Taghi FATEMI GHOMI, M. HAKIMI-ASIABAR, P. HOOSHANGI TABRIZI

Optimization and Modeling of Turning Process for Aluminium - Silicon Carbide Composite Using Artificial Neural Network Models R. JEYAPAUL, S. SIVASANKAR

A Framework for Evaluating Lean Implementation Appropriateness Diogo AURELIO, Antonio GRILO, Virgilio CRUZ MACHADO

Measuring Efficiency of Production Lines Based on Maintenance Factors ; Using DEA Sahar ABBASI, Hadi SHIROUYEHZAD

Comfort Study of Work Environment of Apparel Industry Wathavana Vithanage Randika KOSALA, Nimesha VILASINI, Janaka GAMAGE 


\section{Quality Control \& Management (1)}

Developing a Framework for Six Sigma in Financial Service Institutions - Empirical Evidence from

Expert Interviews

Ayon CHAKRABORTY, Michael LEYER

Improve Burnishing Formation Yield Applying Design For Six Sigma Jianjun WU, Yizhen WANG, Qizhong ZHANG, Pengpeng HUANG

Robust Monitoring of Process Mean Vector in Female Shrouded Connector Production: An

Experience in Malaysia

Rohayu MOHD SALLEH, Maman DJAUHARI

Research of Relationship between Tolerance Allocation and Machine Movement Chain Jiping LU, Shuiyuan TANG, Guanghe LU, Hao SONG

Implementation of Overall Equipment Effectiveness in Wire Mesh Manufacturing Ratapol WUDHIKARN

Strategic Management of the Triple Constraint Trade-off Dynamics - a Polarity Management Approach

C. Jurie VAN WYNGAARD, H.C. PRETORIUS, LeON PRETORIUS

\section{Project Management (1)}

Total Productive Maintenance in a Semiconductor Manufacturing Firm: An Empirical Analysis Kam-Choi NG, Gerald Guan Gan GOH, Uchenna Cyril EZE

Innovation Project Portfolio Management: the Case of Philips Research Sergey FILIPPOV, Herman G. MOOI

Project Risk Management: a New Approach Stefan CREEMERS, Erik DEMEULEMEESTER, Stijn VAN DE VONDER

Exploring Close-optimal Solutions for the Time Constrained Scheduling Problem in Project

Management

Christos KIRIKLIDIS, Konstantios KIRYTOPOULOS, Elena ROKOU

Application of Real Options in Project Portfolio Selection Chengchao WANG, Yongyi SHOU

Risk Factors Influencing Time and Cost Overrun in Multiple D\&B Projects in Malaysia: a Case Study Ramanathan CHIDAMBARAM, Narayanan SAMBU POTTY, Arazi BIN IDRUS

\section{Project Management (2)}

Do Project Managers Need an Operations Research Support Indeed?(A Survey on Polish Project

Managers Attitude towards Operations Research Methods and Tools) Tomasz BLASZCZYK

Dynamic Fuzzy Comprehensive Evaluation of Contract Management in Project Department Yunna WU, Yong HUANG, Wenjun CHEN

Particle Swarm Optimization for Preemptive Project Scheduling with Resource Constraints Fei LI, Changtao LAI, Yongyi SHOU 
An Optimization Model for the Control of Complex Turnkey Projects in Plant Engineering Egon MUELLER, Ralph RIEDEL, Manuela KRONES, Henrik VAY

Team Communications and Academic R\&D Performance: A Case of National Telecommunication Program of Taiwan

Chia-Liang HUNG, Jerome Chih-Lung CHOU, Shan-Jan KUO

Prioritizing Activities on a Building Site Project

Luciana ALENCAR, Adiel ALMEIDA, Caroline MOTA

A Multi-Objective Optimization and Fuzzy Prioritization Approach for Project Risk Responses

Selection

Ebrahim REZAEE NIK, Seyed Hessameddin ZEGORDI, Ahad NAZARI

A Serial Scheme for Minimizing the Duration of Resource-Constrained Projects within Microsoft

Project

Norbert TRAUTMANN, Gianluca BRANDINU

\section{Supply Chain Management (4)}

Reverse Logistics: Implementation in the Industrial Sector of Ecuador Arun KUMAR, Christian VELOZ, Roesfiansjah RASJIDIN

Performance-based MRO Service Contracts with Two Customer Classes

Niak Wu KOH, Roland Y. G. LIM

An Effective Heuristic for Yard Template Design in Land-Scarce Container Terminals

908 Mingkun LI, Shiying LI

How the Effect of Country-of-Origin on Store Brand Moderates Customer's Affection-Conation Link toward Multinational Retailers Yung-Hsin CHEN, Shuo-Chang TSAI, Yi-Shuang WU, Shu-Min LI

Information Sharing in Supply Chain: Modeling the Barriers A. A. PUJARA, R. KANT, M. D. SINGH

Service Impact on Customer Demand and Member Profit in a Supply Chain Rasul JAMSHIDI, Seyyed Mohammad Taghi FATEMI GHOMI

\section{Supply Chain Management (5)}

The Resilience Paradigm in the Supply Chain Management: A Case Study Ana Paula BARROSO, Virginia MACHADO, Virgilio CRUZ MACHADO

Minimizing the Vulnerabilities of Supply Chain: A new Framework for Enhancing the Resilience Umang SONI, Vipul JAIN

Reducing Risk in Supply Chains with Forecasting - An Analysis Richard LACKES, Markus SIEPERMANN

A Supply Chain Coordination Mechanism with Credit Option Contract Considering Backordered 


\section{Safety, Security \& Risk Management}

Management Process Quality and Safety at Organizational Level (A Case Study at an International

Airport)

Mohammad SHAHRIARI, Lennie EDMAN, K. HAMDANI, Pedro AREZES

Emergency Exposure Limits for Toxic Chemicals in Major Hazard Installations of China Hui CUI

Optimal Risk Response Plan of Project Risk Management Amnon GONEN

Modeling a Constraint-based Design Risk Management Tool: An Empirical Study for Collaborative Product Design Jian RUAN, Sheng Feng QIN

IT Can Improve Healthcare Management for Patient Safety - Minimizing risk of blood transfusion with Point-of-Act-System -

Masanori AKIYAMA, Atsushi KOSHIO

Occupational Safety \& Health (OSH) Performance of SMEs: A Structured Framework Enrico CAGNO, Guido Jacopo Luca MICHELI, Celeste JACINTO, Donato MASI

A Clustering Approach to the Operational Resilience Analysis of Key Resource Supply Chains

(KRSC): the Case of Fast Moving Consumer Goods Paolo TRUCCO, David WARD

Electrostatic Hazards of Polypropylene Powders in the Fluidized Bed Reactor 995 K.S. CHOI, K.T. MOON, J.H. CHUNG, X. BI, J. R. GRACE

\section{Information Processing and Engineering}

Coordinating Time-Constrained Multi-Agent Resource Sharing with Fault Detection 1000 Shieu-Hong LIN

A Method for Identifying Process Reuse Opportunities to Enhance the Operating Model Marne De VRIES, Alta Van Der MERWE, Paula KOTZE, Aurona GERBER

Dynamic Partitioning for Enterprise Applications Martin GRUND, Jens KRUEGER, Juergen MUELLER, Alexander ZEIER, Hasso PLATTNER

Pitfalls of Information Technology Management Systems Raj SIRIRAM

Fuzzy Hierarchical Clustering based on Fuzzy Dissimilarity YaQiong LV, Carman Ka Man LEE

A Comparison of Technology Trajectories between the Global and the United States in Smart Grid Siou-Zih LIN, Ssu-Han CHEN, Chun-Chieh WANG, Dar-Zen CHEN

\section{Technology and Knowledge Management (1)}

Knowledge Management Implementation: Analytic Hierarchy Process Methodology 
China

Yilin FAN, Guowei WAN

Applying K-means Clustering and Technology Map in Asia Pacific-Semiconductors Industry

Analysis

Chin Yuan FAN, M. F. LAI, T. Y. HUANG, C. M. HUANG

Roadmapping an Emerging Technology in Clean Energy Industry: A Case Study of Dimethyl Ether

Development in China

Yuan ZHOU, Guannan XU, Jun SU, Tim MINSHALL, Qiang ZHI

Structure of International Research Collaboration in Wind and Solar Energy

Ichiro SAKATA, Hajime SASAKI, Toshihiro INOUE

\section{Technology and Knowledge Management (2)}

A Methodology for Tracking the Impact of Changes in (re)Designing of the Industrial Complex

Product

Nattawut JANTHONG

Dynamic Interactions between Knowledge Creation and Resource Mobilization in R\&D

Management: A Case of the Inkjet Innovation in Japan

Ken HASHIMOTO, Shuzo FUJIMURA

Evaluation of the Sci-tech Service Industry Based on Factor Analysis - A Demonstration Study of 30

Provinces in China

Hongtao YANG, Huiling HUANG

Using Methodologies to Embed Knowledge into the Information Systems Development Process: An Investigation into the IT Sector in China

Younes BENSLIMANE, Zijiang YANG

The Impact of Openness on Innovation Performance of China's Firms: from the Perspective of

Knowledge Attributes

Xiaoting ZHAO, Liang LIANG

Measurement and Improvement of Individual e-Business Capability Chui Young YOON, Byung Hwan KIM

Relations between Corporate Philanthropy and Antecedent Variables: Based on the Empirical Data Xueying TIAN

Key Performance Indicators for Sustainable Manufacturing Evaluation in Automotive Companies Elita AMRINA, Shari MOHD YUSOF

\section{Facilities Planning and Management}

A Fuzzy Set Covering-Clustering Algorithm for Facility Location Problem Rashed SAHRAEIAN, Mohammad Sadeq KAZEMI

The Scenario Based Regret and Min-Max Regret Approach for Location-allocation Model of

Distribution Center, with Uncertain Parameters Mahdi BASHIRI, Amir MOSLEMI

Warehouse Storage Assignment: the Case Study of Camera and Lense Manufacturer Chompoonoot KASEMSET, C. RINKHAM 


\section{Engineering Economy and Cost Analysis}

Production System with Respect for Variable Quantities for an Economical Electric Vehicle

Production

G. SCHUH, Achim KAMPKER, Peter BURGGRAF, Carsten NEE

Cost-effective Planning of Energy-measurement-systems

Egon MUELLER, Markus BUSCHMANN, Kai-Uwe WONNEBERGER

A Review on Models and Practical Methods for Economic Evaluation of Occupational Safety and Health (OSH)

Enrico CAGNO, Guido Jacopo Luca MICHELI, Donato MASI, Celeste JACINTO

Survey on Energy Efficiency Measurements in Heterogenous Facility Logistics Systems Christian PRASSE, Andreas KAMAGAEW, Sebastian GRUBER, Kathrin KALISCHEWSKI, Stefan SOTER,

Michael TEN HOMPEL

Benchmarking in the Public Service Industry: The Italian Water Service Management Sector Corrado LO STORTO

Agent-Based Simulation of Economic Sustainability in Waste-to-Material Recovery Q.Z. YANG, Y.Z. SHENG, Z.Q. SHEN

\section{Service Innovation and Management}

The Activities and Typologies in Service Innovation Design and Deployment:A Socio-Technical

Perspective on University Based Living Lab Hung Chih LAI, Kae Kuen HU, Li Wei CHEN

Service Quality, Brand Image and Price Fairness Impact on the Customer Satisfaction and Loyalty Chi-Chuan WU, Shu-Hsien LIAO, Yin-Ju CHEN, Wei-Lun HSU

The Feasibility of System Dynamic Modeling in Value Assessment of Industrial Services Ville OJANEN, Samuli KORTELAINEN, Sakari HYPPANEN

Intermediating R\&D and Marketing Value Creation by Open Innovation Shu WANG, Jin CHEN, Fang XIE

The Connection Between Customer Value Creation and Innovation Strategy: A Proposed Framework and Its Implication in Fashion Products Chien-Liang KUO, Chien Chiang LIN, Yen-Kwan WU

Service Innovation for the User Interface of an ATM Catering to the Needs of the Student Community Girish KRISHNAN, Sanjay KUMAR, Jithin C.R., Vinay V. PANICKER, R SRIDHARAN

Adoption of New Service Development Tools in the Financial Service Industry Dayu JIN, Kah-Hin CHAI, Kay-Chuan TAN

Identification of Best Practices to Achieve Innovation, Corporate Entrepreneurship and Spinoff in

Chilean Companies Alfonso BASTIAS, Patricio CORTES 


\section{Poster Session 2}

Application of Fuzzy Mathematical Programming to Optimize an Integrated Production-distribution

1195 System

Fardin AHMADIZAR, Mehdi ZEYNIVAND

Supplier Development: a Decision Making Problem Zahra SHARAFI, Jamshid PARVIZIAN

1199

Application of Fuzzy-AHP Extent Analysis for Supplier Selection in an Apparel Manufacturing

Organization

Mohammad Mahmudur RAHMAN, Kazi Badrul AHSAN

A Model for Evaluating Lean, Agile, Resilient and Green Practices Interoperability in Supply Chains Pedro ESPADINHA-CRUZ, Antonio GRILO, Rogerio PUGA-LEAL, Virgilio CRUZ MACHADO

Arena Simulation Model for Multi Echelon Inventory System in Supply Chain Management Kunal PATIL, Kai JIN, Hua LI

Stability of Production Lines with Multiple Delays Narthan Cemal SAADET, Ali Fuat ERGENC

Fuzzy Guidance Strategies for Fair Multi-Agent Negotiation of Wholesale Price Contracts Omar KALLEL, Ines BEN JAAFAR, Lionel DUPONT, Khaled GHEDIRA

A Simulation Comparison Analysis of Effective Pallet Management Scenarios Maria Grazia GNONI, Gianni LETTERA, Alessandra ROLLO

Does Topology Matter? Land Price and Road Network Satoru YAMAMOTO, Yuya KAJIKAWA

Market Information, Scope Economies, and Make-or-Buy Decision under Information Asymmetry Suxiu XU, Qiang $L U$, Xiaoming $H U$

Developing a New Consumption Experience Scale for Taiwanese Fine Foods Culture Ching-Yu LIEN, Shu-Hwa HSIAO

A Model for Carbon Management of Supplier Selection in Green Supply Chain Management Chia-Wei HSU, S. H. CHEN, Cherng-Ying CHIOU

The ADT Evaluation Method Based on MCMC

Lizhi WANG, Xiaoyang LI, Tongmin JIANG, Xiaotian ZHUANG

The Impacts of Common Cause Failures for Two-Unit Parallel Systems from RAMS+C Point of View

Chun-Yuan CHENG, Min WANG, Bee Leng LEE

Redundancy Allocation for Series-Parallel Warm-Standby Systems O. TANNOUS, L. XING, P. RUI, Min XIE, S.H. NG

Simulation-Assisted Estimation of Failure Models with Stochastic Hazard Rates Ke SUN, Songlin CHEN, Zhang WU

A Multi-Objective Identical Parallel Machine Scheduling with Setup and Removal Times with

Deteriorating and Learning Effects Alireza AMINI, Reza TAVAKKOLI-MOGHADDAM, Fardad NIAKAN

Genetic Algorithms and the Cutting Stock Problem Mohsin MALIK, John TAPLIN, Min QIU 
Results

Roohollah MILIMONFARED, Romeo MARIAN, Zeinab HAJIABOLHASANI

Examination of the Effectiveness and Robustness of the Heuristics for Bay-based Quay Crane

Scheduling Problem in Port Container Terminals

Jiang Hang CHEN, Stephen ZHANG, D.H. LEE

Improving Dispatch Operations in Complex Courier Organizations

Laura Paulina LARA AVILA, Fatos ELEZI, Maria CARIDI, Udo LINDEMANN

Project Management for Small Wind Turbines: an Experimental Survey on Activities, Lead Times and Risks

Marcello FERA, Roberto MACCHIAROLI, Salvatore MIRANDA

Composing a Technology Delivery System for an Emerging Energy Technology: The Case of Dye-

Sensitized Solar Cells

Ying GUO, Xuefeng WANG, Donghua ZHU

Innovation Risk-utility Pathway Method Applied to Dye-sensitized Solar Cells

Ying GUO, Xuefeng WANG, Donghua ZHU

Full Service Vehicle Manufacturing: Rise and Fall Alan PILKINGTON, Luciano CIRAVEGNA

A Prescriptive Approach to Understand Customer Needs Using Value-focused Thinking Xinwei ZHANG, Guillaume AURIOL, Claude BARON

Investment Center Framework

Romeo G. MANALO, Marivic V. MANALO

Robustness and Reliability Consideration in Product Design Optimization Under Uncertainty Xiaotian ZHUANG, Rong PAN, Lizhi WANG

System Dynamics Modeling for EFQM Excellence Model: Case Study of a Regional Electricity Company in Iran

Mohammad Dehghani SARYAZDI, Kazem NOGHONDARIAN, Mohammad Saleh OWLIA, Jamal Hosseini $A Z A B A D I$

Control Chart for Monitoring Dependent Binomial Processes

Tsen-I KUO, Cheng-Shih LIN, Tung-Tsan CHEN, Hsin-Hua HUNG

System Integration Issues - Causes, Consequences \& Mitigations Adalberto Coelho SILVA, Geilson LOUREIRO

Process Cascade- and Segmentation-Based Organizational Design: A Case Study Markus KOHLBACHER, Doris WEITLANER

Determining Economic Manufacturing Quantity, the Optimum Process Parameters Based on Taguchi Quadratic Quality Loss Function Under Rectifying Inspection Plan Ismail AL-ME'RAJ, Yahya CINAR, Salih DUFFUAA

Identifying Quality Improvement Opportunities in a Manufacturing Enterprise Stanley FORE

An EWMA - Based Method for Monitoring Polytomous Logistic Profiles

Hamidreza IZADBAKHSH, Rassoul NOOROSSANA, Marzieh ZARINBAL, Amir ZARINBAL, Mohammad Reza SAFAIAN, Majid CHEGENI 


\section{E-Business and E-Commerce}

A Procurement Model in an Electronic Market with Coordination Costs Jishnu HAZRA, B. MAHADEVAN

E-business and E-commerce Applications and Trends in the Retailing Sector in Zimbabwe Charles MBOHWA, Batanai SAMMIE

MOA and TRA in Social Commerce: An Integrated Model

Pei-Lee TEH, Pervaiz Khalid AHMED

The Effects of Psychological Factors on Online Consumer Behavior Shu-Hsien LIAO, Yu-Chun CHUNG

1380

The Research on Relationships between Customers' Perceived Value and Repurchase Intention Yiming XIANG, Lili LI, Xin ZHONG

Information Architecture for Online Review System G. RAJESRI, P. Laras AYUTIRTA

DMTT - An Approach for Business Document Mapping and Transformation in B2B Collaboration Wen Jing YAN, Chong Minsk GOH, Puay Siew TAN, Valliappan RAMASAMY

Influencing Factors of Consumer Intention towards Web Group Buying Guobiao XIE, Jie ZHU, Qiang LU, Suxiu XU

\section{Manufacturing Systems (2)}

A Two-Stage M/G/1 Queue with Discretionary Priority Zhaotong LIAN, Ning ZHAO

Heuristic Algorithm for Two-sided Assembly Line Balancing Problem with Multi-objectives Xiaofeng $H U$

Considering Decision Maker Ideas in Product Mix Problems by Goal Programming Fahimeh TANHAIE, Nasim NAHAVANDI

Optimization of Multi-skilled Operator Allocation to Minimize Inventory Waiting Time Adam BROWN, Fazleena BADURDEEN

Application of Data Mining Techniques to Monitor the Network-controllable Robot's Performance Yongjin (James) KWON, Yongmin PARK, Jungwan HONG

Average Flow Time Estimation of Jobs in a Flexible Manufacturing Cell Consisting of a Number of Identical Machines Jannes SLOMP, Jos A.C. BOKHORST, Rahul CAPRIHAN

Numerical Simulation and Experimental Verification of Electrode Life for Different Coolants and Its Flow in Plasma Cutting Torch M. Senthil KUMAR, B. DHANASEKAR, G. Ranga JANARDHANA, S. PARAMASIVAM, K. S. Jaya KUMAR

An Events-driven Scheduling Algorithm for Two-cluster Tools with Processing Time Windows Xin LI, Richard Y. K. FUNG, Hongyi SUN

An Efficient Tabu Search Approach to Determine Cell Formation Problem with Consideration of Cell Layout Chia-Ching LIN, Chin-Chih CHANG, Feng-Chia LI 


\section{Quality Control \& Management (2)}

Optimization of Multiresponse Problems using Process Capability Index for Batch Manufacturing 1446

Processes

Amirhossein AMIRI, Mahdi BASHIRI, Hamed MOGOUIE

Implementation of Environmental Management in the Austrian Transport Sector - Do Manager's

Attitudes Matter?

Elmar FURST, Peter OBERHOFER

Email Network Analysis for Leadership

Hisato TASHIRO, Antonio LAU, Junichi MORI, Nobuzumi FUJII, Yuya KAJIKAWA

TQM Organizational Development for a Global Manufacturer Kiyoshi SUZUKI, Hisato TASHIRO, Nobuzumi FUJII, Masayoshi USHIKUBO, Ichiro SAKATA

Process Capability Analysis for Non-normal Distribution with Lower Specification Limit

1466 Duygu KORKUSUZ, Hendry RAHARJO, Bo BERGMAN

Synthetic-np Chart for Attributes Salah HARIDY, Zhang WU

Controlling Non-conformities Propagation in Manufacturing. Case Study in an Electromechanical Assembly Plant

Valerie FIEGENWALD, Samuel BASSETTO, Michel TOLLENAERE

\section{Quality Control \& Management (3)}

Profile Monitoring for Poisson Responses

Amirhossein AMIRI, Mehdi KOOSHA, Armaghan AZHDARI

The Effect of an Additional Observation on Covariance Structure Maman DJAUHARI

Effect of Seemingly Unrelated Regression-based Modeling Approach on Solution Quality for

Correlated Multiple Response Optimization Problems Sasadhar BERA, Goutam BARMAN, Indrajit MUKHERJEE

Heuristic and Metaheuristic Structure of Response Surface Methodology in Process Optimization Mahdi BASHIRI, Farshid SAMAEI

The impact of Tolerance Limit on Cost of Quality

Mohamed K. OMAR, Sharmeeni MURUGAN, Rohana ABDULLAH

Decision-making in Process Design Based on Failure Knowledge Wei DAI, Jun YANG

Economic Process Control for Multivariate Quality Characteristics with Hotelling's T-squared Charts under Gamma Shock Model

Feng-Chia LI, Peng-Kai WANG, Li-Lon YEH, Sheng-Wen HONG

\section{Reliability and Maintenance Engineering (1)}

Integration of Maintenance Stategies for Improved Asset Reliability and Availability N. K. K. PRASANNA, Shakti AKULA, Tushar N. DESAI 
Resources

Majid BAZRAFSHAN, Shahrzad NIKGHADAM, Shaomin WU

Reuse Oriented Group Maintenance Scheduling Based on Hybrid Genetic Algorithm and Tabu Search

1524 Jihong YAN, Dingguo HUA, Zimo WANG

State Space Model Based Reliability and Sensitivity Analysis for Multistage Manufacturing Process Faping ZHANG, Aiqing CHEN, Hong JING, Yan YAN, Hanbo QIAN

Software Reliability Modelling and Optimization for Multi-release Software Development Processes Qingpei HU, P. RUI, Min XIE, S.H. NG, Gregory LEVITIN

Multi Up-gradation Software Reliability Growth Model with Faults of Different Severity Amir Hossein SOLEIMAN GARMABAKI, Anu.G AGGARWAL, Pramod Kumar KAPUR

Performance-based Burn-in for Products Sold with Warranty Zhisheng YE, Loon Ching TANG, Min XIE

System Dynamics Simulation for Constructing Maintenance Management of Ship Machinery Dhimas HANDANI, Kenji ISHIDA, Shintaro NISHIMURA, Surya HARIYANTO

\section{Reliability and Maintenance Engineering (2)}

Reliability of Surveillance Mission with Unmanned Aerial Vehicles Kien Ming NG, Jun JIANG, Rui PENG, Kim Leng POH, Kwong Meng TEO

Reliability-based Robust Design Optimization: A Comparative Study Vijay RATHOD, Om Prakash YADAV, Ajay Pal Singh RATHORE, Rakesh JAIN

Exploring Impacts of Single Failure Propagation between SCADA and SUC Cen NAN, Irene EUSGELD

Human Factor in Maintenance Performance Measurement Diego GALAR, Christer STENSTROM, Aditya PARIDA, Rupesh KUMAR, Luis BERGES

A Maintenance Service Contract for A Warranted Product

Hennie HUSNIAH, Udjianna S. PASARIBU, Abdul Hakim HALIM, Bermawi ISKANDAR

Expert-Based FMEA of Wind Turbine System Milton Kumar DAS, Subhash Chandra PANJA, Sunetra CHOWDHURY, Shyamapada CHOWDHURY, Andreas I ELOMBO

Condition-based Maintenance for Systems Under Dependent Competing Failures 1586 Liangpen CHEN, Zhisheng YE, Boray HUANG

\section{Technology and Knowledge Management (3)}

A Model for Linking Knowledge Management Strategies, Critical Success Factors, Knowledge

Management Practices and Organizational Performance; the case of Iranian Universities Afarin AKHAVAN, Mohammad Saleh OWLIA, Mostafa JAFARI, Yahya ZARE

Identifying Mapping Relationships between Functions and Technologies: an Approach based on Association Rule Mining Linda ZHANG, Roger JIAO

Ranking of Technology Transfer Barriers in Developing Countries; Case Study of Iran's Biotechnology Industry Khashayar YAZDANI, Kourosh YAZDANI RASHVANLOUEI, K. ISMAIL 
Managing Supply Chain Knowledge in the New Product Development Process: a Social Network

Analysis Approach

Marianna MARRA, William HO, John S. EDWARDS

An Ontological Approach for Program Management Lessons Learned: Case Study at Motorola

Penang Design Centre

Yu-N CHEAH, Soo Beng KHOH, Ghee Beng OOI

Optimization of a Knowledge-based System by a Meta-heuristic Approach for the Automotive

Diagnosis

Armin AZARIAN, Ali SIADAT, Patrick MARTIN

Defining Technology Entrepreneurship

Markus SPIEGEL, Christian MARXT

Towards the Integration of Technological, Organizational and Human Subsystems of Organizations to

Enhance Productivity

Mohammed Aminu SANDA, Jan JOHANSSON

\section{Technology and Knowledge Management (4)}

Identification and Classification of Human Error in Process Model Development Alexander NIELEN, Denise KOLTER, Susanne MUTZE-NIEWOHNER, Christopher M. SCHLICK

Technological Capability Building in Network Environments: the Moderating Effects of Governance

Structure Suli ZHENG, Zengyuan WU

Open Innovation in Chinese High-tech Enterprises: An Empirical Research Based on Zhejiang Province

Fang LIU, Gang ZHENG

The Paradoxical Property of Knowledge in Organizations J. Ajith KUMAR

Technology Manager's Radar Screen: Monitoring Competitors' Innovation Performance Chung-Huei KUAN, Huei-Ru DONG, Mu-Hsuan HUANG, Dar-Zen CHEN

The Impact of Absorptive Capacity on the Ex-Post Adoption of Agile Methods: The Case of Extreme Programming Model Bouchaib BAHLI, Younes BENSLIMANNE, Zijiang YANG

Technology, Quality and Trade in the Apple Industry Kayla LOPUCH, Laura SYRETT, John CONRAD, Harm-Jan STEENHUIS

\section{Systems Modeling and Simulation (1)}

A Robust-Gain-Scheduled Methodology for Process Parameter Design and Control with Application

Design and Modeling of Roll-to-Roll Manufacturing System Using Simulation Techniques Laura Xiao Xia XU, Chin Wei GAN, Feng Yu WANG, Ma BIN, Roland LIM

Design of Comminution Circuits for Improved Productivity Using a Multi-Objective Evolutionary

Algorithm (MOEA)

Samson MHLANGA, Jabulani NDLOVU, Charles MBOHWA, Michael MUTINGI 
Systems Thinking for Modeling Risk Propagation in Supply Networks

A UML Approach for the Design of Reconfigurable Manufacturing Simulation Models

Bayesian Calibration of Stochastic Computer Models

Wafer Lot Release Policies Based on the Continuous and Periodic Review of WIP Levels Khaled S. EL-KILANY

A Framework for Solving the Optimal Display Quantities with Equality Constraint

Takuya SUGANUMA, Hiroyuki GOTO

\section{Systems Modeling and Simulation (2)}

Principles for Modelling Business Processes Antonie VAN RENSBURG

Resolution of Resource Conflict in a Max-Plus Linear Representation -Case of a Single ProjectShotaro YOSHIDA, Hirotaka TAKAHASHI, Hiroyuki GOTO

A Queuing System with Risk-Averse Customers: Sensitivity Analysis of Performance Carlos Arturo DELGADO, Ann van ACKERE, Erik LARSEN

Balancing Multi-robot Prioritized Task Allocation: a Simulation Approach M. ELANGO, S.P. NACHIAPPAN

Modeling Patient Visits to Accident and Emergency Department in Hong Kong M. XU, T. C. WONG, K. S. CHIN, S. Y. WONG, K. L. TSUI

Evaluation of a Supply Chain Performance Using a Fuzzy Decision Support System Isabel L. NUNES, Sara FIGUEIRA, Virgilio CRUZ MACHADO

Assessing Quality of Manufacturing Organizations - A Graph Theoretic Approach Mohit SINGH, I.A. KHAN, Sandeep GROVER, S.C. GUPTA

On Storage Capacity Pooling through the Supply Hub in Industrial Park (SHIP): The Impact of

Demand Uncertainty Xuan QIU, George Q. HUANG

\section{Poster Session 3}

Efficiency Improvement on Job Scheduling by Using Genetic Algorithm: A Case Study in Electronic Industry Budtree LIMWANICH, Rati WONGSATHAN

Process Family Planning: a Methodology Integrating Petri Nets and Knowledge-based Systems Linda ZHANG, Qianli XU

Shifting Economic Bottleneck Identification Junqiang WANG, Jian CHEN, Shuo WANG, Yingfeng ZHANG, Shudong SUN 
A Study on Audit Fees Decision Making: Evidence from China Stock Market Xin LI, Xiaobo ZHU

Data Pre-Processing by Genetic Algorithms for Bankruptcy Prediction Chih-Fong TSAI, Jui-Sheng CHOU

To Form a Smaller World in the Research Realm of Hierarchical Decision Models Bing WANG, Xiaotian YAO

Threat Evaluation Model of Targets Based on Information Entropy and Fuzzy Optimization Theory Li-Ying FENG, Qing XUE, Min-xia LIU

Study of Deformation and Compensation for Ram-Quill Type Spindle Chia-Hui TANG, Ching-Feng CHANG, Tsair-Rong CHEN

Fuzzy Classification of Gas Power Plant Spare Parts by Combination Statistical Classification

Technique, SAW, ABC Analysis Shahrokh HEMATYAR

The Impact of Work Design Concept on Manufacturing Performance: A Process Sector Case Study Nimesha VILASINI, Udaya KAHANGAMAGE, Janaka GAMAGE, Wathavana Vithanage Randika KOSALA

Designing an Integrated Order Fulfillment System for Configure-to-Order Production Linda ZHANG, Qianli XU

Planning Process Families with a Knowledge-based System Linda ZHANG, Qianli XU, Yongyi SHOU

Performance Evaluation of Knowledgeable Manufacturing Systems Using Petri Nets Considering

Dynamic Events Youlong LV, Jie ZHANG

Using Bayesian Networks and Importance Measures to Indentify Tumour Markers for Breast Cancer Shubin SI, Guanmin LIU, Zhiqiang CAI, Peng XIA

Identifying Critical Business Rules Using Rough Set Theory Mohamad AGHDASI, Ehsan MALIHI, Fatemeh GHORBANI

Apply HLM to Analyze Government Policies Influence the Accessibility Of Sidewalks Ching-Tsung HUNG

Confidence Interval Estimation of Software Reliability Growth Models Derived from Stochastic

Differential Equations Chih-Chiang FANG, Chun-Wu YEH

A Genetic Algorithm Approach for Modelling and Optimisation of MAJSP- Part I:Modeling Roohollah MILIMONFARED, Romeo MARIAN, Zeinab HAJIABOLHASANI

On The Development of Adoption of Newer Successive Technologies Using Stochastic Differential Equation P.C. JHA, Kuldeep CHAUDHARY, Anshu GUTPA

A Framework Algorithm for a Real-World Variant of the Vehicle Routing Problem Vu PHAM, Tien DINH

A Branch and Cut Algorithm for the Multi-Vehicle One-to-One Pickup and Delivery Problem with Split Loads Temel ONCAN, Dilek Tuzun AKSU, Guvenc SAHIN, Mustafa SAHIN

Research on Rapid Design Plan For Engine Based on Human Factors Engineering 1869 Han YU, Oing XUE, Minxia LIU 
Towards Human Stability in Transport Systems

Philippe RICHARD, Vincent BENARD, Frederic VANDERHAEGEN, Patrice CAULIER

Work Motivation and Job Performance of Frontline Employees: the Mediating Role of Organizational 1878 Commitment Panagiotis TRIVELLAS

The Human Factors Analysis of Marine Accidents Based on Goal Structure Notion Tingting DAI, Haiyan WANG

Situational Awareness Needs for System Interaction Design D'oria ROSLI, Azizah ABDUL RAHMAN, Rose Alinda ALIAS

A Design of 3D Modeling Virtual Fitting Project for Online Shopping Pangli ZUO, Yi ZHAO

Achieving Platform Leadership: Application of Inverting and Porting in System Development Jerome Chih-Lung CHOU, Chia-Liang HUNG, W. T. LI

Uncertainty Analysis on Number of Fatalities in Building Fires Guanquan CHU, Jinhui WANG

Composable Correlation Mining of Cloud Service in Cloud Manufacturing Hua GUO, Lin ZHANG, Fei TAO, Zhiyun REN, Yongliang LUO

Energy Adaptive Immune Genetic Algorithm for Collaborative Design Task Scheduling in Cloud Manufacturing System Yuanjun LAILI, Lin ZHANG, Fei TAO

Design of a Lean Development Framework U. DOMBROWSKI, Thimo ZAHN

Study on the Variation and Survival Factors in the Business Evolution Process Based on

Organizational Ecology Jie HOU, Qiang LU, Yongjiang SHI

A New Practical Conformance Testing Method Based on Standard Zhou JIANG, Li ZHENG, Fujiang LIU, Qing XIANG 


\title{
Key Performance Indicators for Sustainable Manufacturing Evaluation in Automotive Companies
}

\author{
E. Amrina ${ }^{1}$, S. M. Yusof ${ }^{2}$ \\ ${ }^{1}$ Department of Industrial Engineering, Andalas University, Padang, Indonesia \\ ${ }^{2}$ Department of Manufacturing \& Industrial Engineering, Universiti Teknologi Malaysia, Johor, Malaysia \\ (elita@ft.unand.ac.id, shari@fkm.utm.my)
}

\begin{abstract}
The automotive industry is regarded as one of the most important and strategic industry in manufacturing sector. It is the largest manufacturing enterprise in the world and one of the most resource intensive industries of all major industrial system. However, its products and processes are a significant source of environmental impact. Thus, there is a need to evaluate sustainable manufacturing performance in this industry. This paper proposes a set of initial key performance indicators (KPIs) for sustainable manufacturing evaluation believed to be appropriate to automotive companies, consisting of three factors divided into nine dimensions and a total of 41 sub-dimensions. A survey will be conducted to confirm the adaptability of the initial KPIs with the industry practices. Future research will focus on developing an evaluation tool to assess sustainable manufacturing performance in automotive companies.
\end{abstract}

Keywords - Automotive, key performance indicators, manufacturing performance, sustainable manufacturing

\section{INTRODUCTION}

Sustainability has becoming an increasingly important issue amongst companies around the world. It is a critical and timely topic [1], a major concern internationally over the last decade [2], a major competitive factor for many manufacturing companies [3], and an important concept to survive the competitive environment [4]. Increasing concerns to sustainability have forced manufacturing companies to consider sustainability into their strategies and activities.

In response to the growing sustainability concerns, manufacturing companies have to formulate measures to evaluate sustainable manufacturing performance, aiming at integration of sustainability aspects. Generally, sustainability is evaluated by environment, social, and economic; known as the three pillars of sustainability.

Although literature on sustainability is abundant and growing, very few studies have actually integrated sustainability into manufacturing performance. Sustainability has been integrated into manufacturing management areas such as product development ([2], [5]), supply chain management ([6], [7]), lean manufacturing [8], and supplier evaluation and selection [9].

In this research, attempt is made to integrate sustainability into manufacturing performance by incorporating manufacturing performance indicators with sustainable manufacturing indicators. As a result, a set of initial Key Performance Indicators (KPIs) for sustainable manufacturing evaluation is proposed. This study focused on automotive industries. The automotive industry has regarded as one of the most important and strategic industry in manufacturing sector and the use of sustainable manufacturing in this industry is very important. This paper culminates in a discussion of the development of a questionnaire to meet the purpose of this study, which is to investigate sustainable manufacturing evaluation KPIs relevant to automotive companies.

\section{LITERATURE REVIEW}

\section{A. Manufacturing Performance}

Manufacturing performance is critical to the success of many firms. Superior performance leads to the competitiveness. In order to stay competitive, manufacturing companies must regularly evaluate their performance. Thus, it is vital for manufacturing companies to identify and ensure good performance in the global competition.

Performance evaluation can be used in guiding organizational change and development [10] and to describe and review the historical performance as well as to set performance targets for the future [11]. Performance indicators do not simply describe what has happened; they influence what will happen, as they provide information for decision maker to make decisions which may affect the future competitive position of the organization [12]. The role of manufacturing performance indicators is to reflect the current state of manufacturing situation, to monitor and control operational efficiency, to drive improvement programme, and to gauge the effectiveness of manufacturing decisions [13]. Four of the most commonly cited indicators to evaluate manufacturing performance are quality, cost, delivery, and flexibility [14].

A literature review was carried out in an attempt to determine indicators commonly used in manufacturing performance evaluation based on those four indicators. A summary of the indicators reviewed is presented in Table I. It can be seen that quality, cost, delivery, and flexibility are most commonly used indicators of manufacturing performance evaluation. It is believed that these indicators are important and relevant and therefore will be used for further development in this research. 
TABLE I

SUMMARY OF MP INDICATORS USED BY AUTHORS

\begin{tabular}{|c|c|c|c|c|c|c|c|c|c|c|}
\hline \multirow{2}{*}{ Literature } & \multicolumn{10}{|c|}{ MP Indicators used } \\
\hline & 1 & 2 & $\overline{3}$ & 4 & 5 & 6 & 7 & 8 & 9 & 10 \\
\hline [15] & * & * & * & * & & & & & & \\
\hline [16] & * & & & * & & & & & & \\
\hline [17] & * & & * & * & $*$ & $*$ & & & & \\
\hline [18] & * & & * & & * & * & & & & \\
\hline [19] & * & * & * & * & $*$ & & & & & \\
\hline [14] & * & & & * & * & * & * & & & \\
\hline [20] & * & * & * & * & * & & & & & \\
\hline [21] & * & * & * & * & * & & & * & & \\
\hline [22] & * & * & * & & & & & & & \\
\hline [23] & * & & $*$ & & & $*$ & * & & * & \\
\hline [24] & * & * & & * & & & & * & & \\
\hline [25] & * & * & * & * & & & & & & \\
\hline [26] & * & & * & & & * & * & & & \\
\hline [27] & * & * & & * & $*$ & & & & & \\
\hline [28] & * & * & * & * & & & * & & & \\
\hline [29] & * & * & * & * & & & & & & \\
\hline [30] & * & * & * & & $*$ & * & & & & \\
\hline [31] & * & & & & & * & $*$ & & * & * \\
\hline [32] & * & * & * & * & & & & * & & \\
\hline [33] & * & * & * & & & * & & & & \\
\hline [7] & * & * & * & * & & & & & & \\
\hline [34] & $*$ & * & * & * & & & & & & \\
\hline [35] & * & * & * & * & * & $*$ & & & & \\
\hline [36] & * & * & * & * & * & & $*$ & & & \\
\hline [37] & $*$ & $*$ & & $*$ & & & & & & \\
\hline
\end{tabular}

\section{B. Sustainable Manufacturing}

The US Department of Commerce [38] define sustainable manufacturing as the creation of manufactured products that minimize negative environmental impacts, conserve energy and natural resources, are safe for employees, communities and consumers and are economically sound. According to OECD, the general principle of sustainable manufacturing is to reduce the intensity of materials use, energy consumption, emissions, and the creation of unwanted by-products while maintaining, or improving, the value of products to society and to organizations [39].

Sustainable manufacturing is currently a very important issue for governments and industries worldwide [40]. Achieving sustainability in manufacturing activities have been recognized as a critical need due to diminishing non-renewable resources, stricter regulations related to environment and occupational safety, and increasing consumer preference for environmentally-friendly products [41]. It was suggested that sustainable manufacturing must respond to environmental, economical, and social challenges [42].

A review on the sustainable manufacturing indicators was conducted and is summarized based on the triple bottom line of sustainability in Table II. It can be concluded that environmental performance is regarded as the most important indicator in evaluating sustainable manufacturing performance. All the studies considered environmental performance as sustainable manufacturing measure. Social performance is used in the following consideration and lastly, economic performance is used in a low level. The social and economic performance received the least attention in the existing sustainable manufacturing performance measures.

Table II shows studies which have considered all the three factors of environmental, social, and economic performance in evaluating sustainable manufacturing are in a low level. Most studies only focused on the environmental factor alone. However, for an effective sustainable manufacturing evaluation, all the three factors should be considered in the same equal level.

TABLE II

COMPARISON OF SOME PREVIOUS KPI STUDIES

\begin{tabular}{lcccl}
\hline \multirow{2}{*}{ Author } & \multicolumn{2}{c}{ Sustainability factors considered } & Final \\
\cline { 2 - 4 } & Environmental & Social & Economic & instrument \\
\hline$[43]$ & $*$ & $*$ & $*$ & 22 indicators \\
{$[44]$} & $*$ & $*$ & $*$ & 32 indicators \\
{$[45]$} & $*$ & $*$ & & 12 indicators \\
{$[46]$} & $*$ & $*$ & $*$ & 34 indicators \\
{$[47]$} & $*$ & & $*$ & 21 indicators \\
{$[48]$} & $*$ & $*$ & & 24 indicators \\
{$[49]$} & $*$ & & & 6 indicators \\
{$[7]$} & $*$ & & $*$ & 16 indicators \\
{$[50]$} & $*$ & $*$ & $*$ & 26 indicators \\
{$[51]$} & $*$ & $*$ & $*$ & 22 indicators \\
{$[52]$} & $*$ & $*$ & & 20 indicators \\
{$[53]$} & $*$ & $*$ & $*$ & 44 indicators \\
{$[41]$} & $*$ & $*$ & $*$ & 40 indicators \\
{$[54]$} & $*$ & $*$ & $*$ & 28 indicators \\
{$[55]$} & $*$ & $*$ & $*$ & 32 indicators \\
{$[8]$} & $*$ & $*$ & & 30 indicators \\
\hline
\end{tabular}

\section{THE INITIAL KPI}

Based on a review on previous studies of the manufacturing performance indicators and the sustainable manufacturing indicators, the authors have developed a set of initial KPIs for sustainable manufacturing evaluation in automotive companies.

The initial KPIs have been constructed from the integration of manufacturing performance indicators and sustainable manufacturing indicators. The initial KPIs have adopted the triple bottom line of sustainability consisting of environmental, economic, and social performance factors. Four manufacturing performance indicators of quality, cost, delivery, and flexibility are incorporated into the initial KPIs as economic performance dimensions. The other dimensions are derived from the literature.

Finally, the initial KPIs consist of three factors of environmental, economic, and social performance and further divided into nine dimensions. A total of $41 \mathrm{sub}-$ dimensions was then adopted and modified from relevant literature as shown in Table III. 
TABLE III

INITIAL KPI OF SUSTAINABLE MANUFACTURING EVALUATION

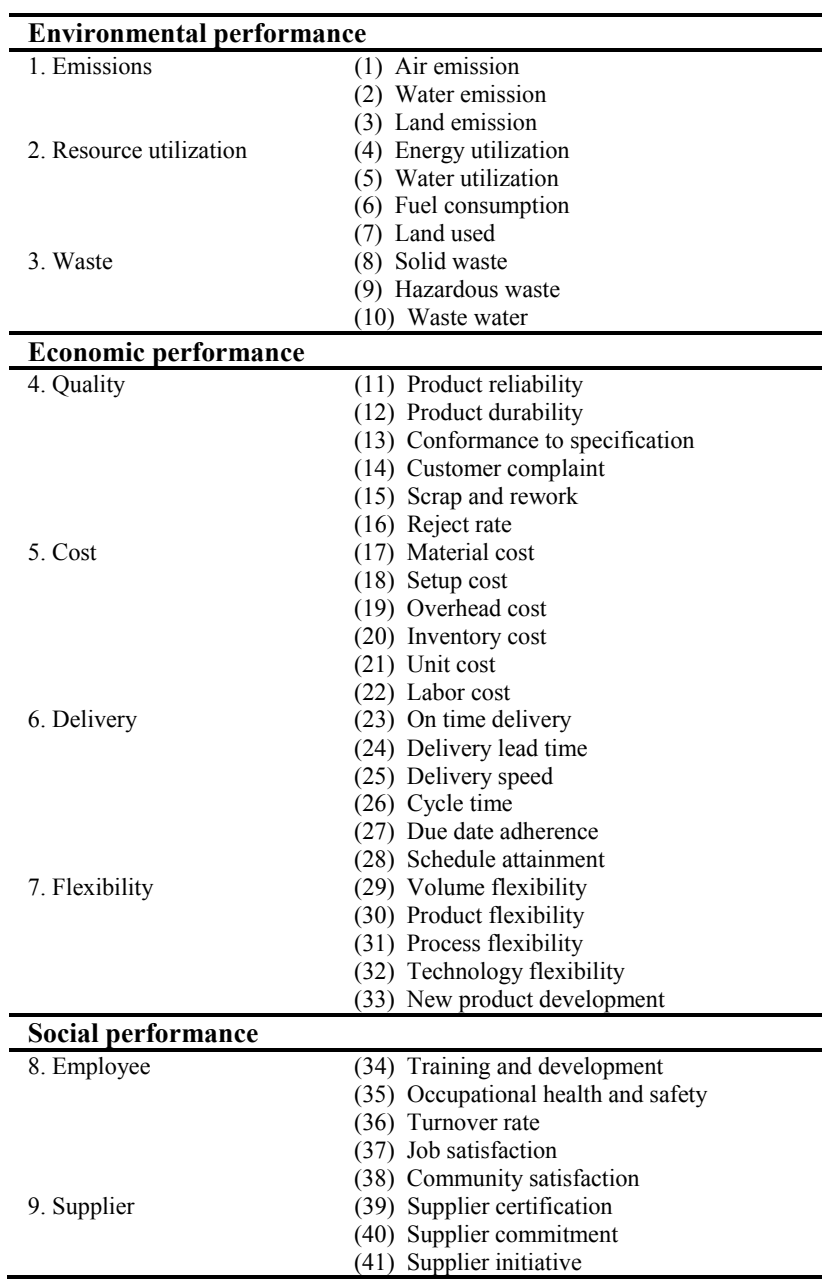

\section{PILOT STUDY}

In order to investigate these KPIs of sustainable manufacturing in automotive companies, a questionnaire was developed. The questionnaire was divided into three main sections: (i) background information; (ii) perception of sustainable manufacturing; and (iii) perceived importance of the initial KPIs. The first section was intended to obtain some basic information, such as business size, types of certification gained, and experience in automotive industry as well as on sustainable manufacturing initiative. The second section on sustainable manufacturing perception provides the drivers, barriers, and benefits on which respondents were asked to rank their level of agreement. In the last section, respondents were asked to rank their level importance of the initial KPIs. These results will be used to develop a set of KPIs in evaluating sustainable manufacturing.

A pilot study was conducted to validate and improve the questionnaire, in terms of the questions and statements content, wording, sequence, and also potential participant interest. A total of 16 forms were distributed to two groups of sustainable manufacturing experts: practitioners in automotive industry and professionals (academics and consultants). Nine responses were received, thus giving a $56 \%$ response rate.

The comments were generally concerned on questions and statements wording. For the initial KPIs, some terms was edited and corrected, for example, "water emission" was changed to "water pollution", "land emission" was changed to "land contamination", and "due date adherence" was changed to "due date compliance". One sub-element of cost element (i.e. unit cost) was removed, and rework cost was added as a new subelement. In this way, the questionnaire was greatly improved. The questions and statements were corrected and improved in order to make them more clearly and accurate.

In short, the questionnaire was validated through pilot study and provided improvement opportunities for the researchers before conducting the full survey. The survey will be conducted to Malaysian automotive companies which manufacture parts and accessories for motor vehicles and their engines listed in Federation of Malaysian Manufacturers (FMM) Directory.

\section{CONCLUSION}

The automotive companies are under intense pressure to reduce environmental impacts of their products and operations. For sustainability, they should try to aim at a balance amongst economic development, environmental protection and social equity. It is a big challenge for the automotive companies, particularly Malaysia, to give serious attention on sustainability.

Although sustainability issues have been widely growing for many years, only few studies have been conducted on incorporating sustainability into manufacturing performance. There is yet to be a standard set sustainable manufacturing performance indicators. Although some studies have investigated indicators for sustainable manufacturing, only few have considered the triple bottom line of sustainability on the same equal level.

This study tries to integrate sustainability with manufacturing performance and has incorporated them into sustainable manufacturing indicators. As a result, a set of initial KPIs for sustainable manufacturing evaluation in automotive companies was proposed.

A questionnaire has been developed to be used as the instrument for investigating the KPIs in industry. It was piloted using sustainable manufacturing experts and practitioners in automotive industry. The questionnaire was validated and improved upon before being used in the main survey, which is the next stage of this research. Future research will focus on investigation of the KPIs for sustainable manufacturing evaluation and provide a basis for developing a sustainable manufacturing evaluation tool that will be useful for the automotive companies. 


\section{ACKNOWLEDGMENT}

The authors would like to thank to the Ministry of National Education, Indonesia and University Teknologi Malaysia RU Grant.

\section{REFERENCES}

[1] J. D. Linton, R. Klassen, and V. Jayaraman, "Sustainable supply chains: an introduction", Journal of Operations Management, vol. 25, no. 6, pp. 1075-1082, 2007.

[2] L. H. Mien, L. W. Feng, R. Gay, and K. Leng, "An integrated manufacturing and product services system (IMPSS) concept for sustainable product development", in Proceedings of $4^{\text {th }}$ International Symposium on Environmentally Conscious Design and Inverse Manufacturing, Eco-Design 2005, Tokyo, Japan, pp. 656662.

[3] R. Seidel, M. Shahbazpour, and M. Oudshoorn, "Implementation of sustainable manufacturing practices in SMEs - case study of a New Zealand furniture manufacturer", in Proceedings of $13^{\text {th }}$ CIRP International Conference on Life Cycle Engineering, LCE2006, Leuven, Belgium, pp. 249-254.

[4] M. Bevilacqua, F. E. Ciarapica, and G. Giacchetta, "Development of a sustainable product lifecycle in manufacturing firms: a case study", International Journal of Production Research, vol. 45, no. 18-19, pp. 4073-4098, 2007.

[5] S. Kara, I. Honke, and H. Kaebernick, "An integrated framework for implementing sustainable product development" in Proceedings of $4^{\text {th }}$ International Symposium on Environmentally Conscious Design and Inverse Manufacturing, Eco-Design2005, Tokyo, Japan, pp. 684- 691.

[6] J. Koplin, S. Seuring, and M. Mesterharm, "Incorporating sustainability into supply management in the automotive industry - the case of the Volkswagen AG", Journal of Cleaner Production, vol. 15, no. 11-12, pp. 1053-1062, 2007.

[7] S. Vachon, and R. D. Klassen, "Environmental management and manufacturing performance: the role of collaboration in the supply chain", International Journal of Production Economics, vol. 111, no. 2, pp. 299-315, 2008.

[8] C. Herrmann, A. Zein, S. Thiede, L. Bergmann, and R. Bock, "Bringing sustainable manufacturing into practice the machine tool case", in Proceedings of the Global Conference on Sustainable Product Development and Life Cycle Engineering: Sustainability and Remanufacturing VI 2008, Busan, Korea, pp. 8-16.

[9] S. Ladd, and F. Badurdeen, "Supplier sustainability evaluation and selection", in Proceedings of the 2010 Industrial Engineering Research Conference, Cancun, Mexico, pp. 1-6.

[10] K. M. G. Mola, "A methodology to measure the performance of manufacturing systems", Ph.D. Dissertation, Department of Industrial Engineering, University of Houston, Houston, Texas, 2004.

[11] A. Ramaa, T. M. Rangaswamy, and K. N. Subramanya, "A review of literature on performance measurement of supply chain network" in Proceedings of $2^{\text {nd }}$ International Conference on Emerging Trends in Engineering and Technology 2009, Nagpur, India, pp. 802-807.
[12] H. S. Jagdev, A. Brennan, and J. Browne, Strategic decision making in modern manufacturing, USA, Kluwer Academic Publishers, 2004.

[13] K. K. B. Hon, "Performance and evaluation of manufacturing systems", CIRP Annals - Manufacturing Technology, vol. 54, no. 2, pp. 139-154, 2005.

[14] M. Hudson, A. Smart, and M. Bourne, "Theory and practice in SME performance measurement systems", International Journal of Operations \& Production Management, vol. 21, no. 8, pp. 1096-1115, 2001.

[15] G. P. White, "A survey and taxonomy of strategy-related performance measures for manufacturing", International Journal of Operations \& Production Management, vol. 16, no. 3, pp. 42-61, 1996.

[16] A. Rangone, "An analytical hierarchy process framework for comparing the overall performance of manufacturing departments", International Journal of Operations \& Production Management, vol. 16, no. 8, pp. 104-119, 1996.

[17] M. H. Small, "Assessing manufacturing performance: an advanced manufacturing technology portfolio perspective", Industrial Management \& Data Systems, vol. 99, no. 6, pp. 266-277, 1999.

[18] J. Mapes, M. Szwejczewski, and C. New, "Process variability and its effect on plant performance", International Journal of Operations \& Production Management, vol. 20, no. 7, pp. 792-808, 2000.

[19] D. Medori, and D. Steeple, "A framework for auditing and enhancing performance measurement systems", International Journal of Operations \& Production Management, vol. 20, no. 5, pp. 520-533, 2000.

[20] A. Toni, and S. Tonchia, "Performance measurement systems: Models, characteristics and measures", International Journal of Operations \& Production Management, vol. 21, no. 1/2, pp. 46-70, 2001.

[21] M. Yurdakul, "Measuring a manufacturing system's performance using Saaty's system with feedback approach", Integrated Manufacturing Systems, vol. 13, no. 1, pp. 25-34, 2002.

[22] T. Christiansen, W. L. Berry, P. Bruun, and P. Ward, “A mapping of competitive priorities, manufacturing practices, and operational performance in groups of Danish manufacturing companies", International Journal of Operations \& Production Management, vol. 23, no. 10, pp. 1163-1183, 2003.

[23] A. B. Abdel-Maksoud, "Manufacturing in the UK: contemporary characteristics and performance indicators", Journal of Manufacturing Technology Management, vol. 15, no. 2, pp. 155-171, 2004.

[24] T. Grunberg, "Performance improvement: towards a method for finding and prioritising potential performance improvement areas in manufacturing operations", International Journal of Productivity and Performance Management, vol. 53, no. 1, pp. 52-71, 2004.

[25] M. S. Diaz, M. J. A. Gil, and J. A. D. Machuca, "Performance measurement systems, competitive priorities, and advanced manufacturing technology: some evidence from the aeronautical sector", International Journal of Operations \& Production Management, vol. 25, no. 8, pp. 781-799, 2005.

[26] M. Gosselin, “An empirical study of performance measurement in manufacturing firms", International Journal of Productivity and Performance Management, vol. 54, no. 5/6, pp. 419-437, 2005.

[27] A. Neely, M. Gregory, and K. Platts, "Performance measurement system design", International Journal of 
Operations \& Production Management, vol. 25, no. 12, pp. 1228-1263, 2005.

[28] R. Tarigan, "An evaluation of the relationship between alignment of strategic priorities and manufacturing performance", International Journal of Management, vol. 22, no. 4, pp. 586-597, 2005.

[29] K. O. Cua, K. E. McKone-Sweet, and R. G. Schroeder, "Improving performance through an integrated manufacturing program", The Quality Management Journal, vol. 13, no. 3, pp. 45-60, 2006.

[30] M. Meybodi, "Internal manufacturing strategy audit: the first step in integrated strategic benchmarking", Benchmarking: An International Journal, vol. 13, no. 5, pp. 580-595, 2006.

[31] C. F. Gomes, M. M. Yasin, and J. V. Lisboa, "An empirical investigation of manufacturing performance measures utilization: the perspective of executives and financial analysts", International Journal of Productivity and Performance Management, vol. 56, no. 3, pp. 187-204, 2007.

[32] A. Golec, and H. Taskın, "Novel methodologies and a comparative study for manufacturing systems performance evaluations", Information Sciences, vol. 177, no. 23, pp. 5253-5274, 2007.

[33] I. P. S. Ahuja, and J. S. Khamba, "An evaluation of TPM initiatives in Indian industry for enhanced manufacturing performance", "International Journal of Quality \& Reliability Management", vol. 25, no. 2, pp. 147-172, 2008.

[34] R. H. Huang, C. L. Yang, and H. L. Shih, "A manufacturing performance evaluation model for notebook computer manufacturers", in Proceedings of IEEE International Conference on Industrial Engineering and Engineering Management, IEEM2009, Hong Kong, pp. 2324-2328.

[35] C. Yang, S. Chuang, and R. Huang, "Manufacturing evaluation system based on AHP/ANP approach for wafer fabricating industry", Expert Systems with Applications, vol. 36, no. 8, pp. 11369-11377, 2009.

[36] K. G. E. Mola, and H. Parsaei, "Dimensions and measures of manufacturing performance measurement", in Proceedings of $40^{\text {th }}$ IEEE International Conference on Computers and Industrial Engineering 2010. Hyogo-Japan, pp. 1-6.

[37] V. F. Yu, and K. Hu, "An integrated fuzzy multi-criteria approach for the performance evaluation of multiple manufacturing plants", Computers \& Industrial Engineering, vol. 58, no. 2, pp. 269-277, 2010.

[38] US Department of Commerce, "Sustainable manufacturing initiative", in Proceedings of the $2^{\text {nd }}$ Annual Sustainable Manufacturing Summit 2009, Chicago, USA.

[39] OECD, "Sustainable manufacturing and eco-innovation: towards a green economy", Organization for Economic Cooperation and Development, 2009.

[40] G. Seliger, H-J., Kim, S. Kernbaum, and M. Zettl, "Approaches to sustainable manufacturing", International Journal of Sustainable Manufacturing, vol. 1, no. 1/2, pp. 58-77, 2008.

[41] A. D. Jayal, F. Badurdeen, O.W. Dillon Jr., and I. S. Jawahir, "Sustainable manufacturing: modeling and optimization challenges at the product, process and system levels", CIRP Journal of Manufacturing Science and Technology, vol. 2, no. 3, pp. 144-152, 2010.

[42] F. Jovane, H. Yoshikawa, L. Alting, C. R. Boer, E. Westkamper, D. Williams, M. Tseng, G. Seliger, and A. M. Paci, "The incoming global technological and industrial revolution towards competitive sustainable manufacturing",
CIRP Annals - Manufacturing Technology, vol. 57, no.2, pp. 641-659, 2008.

[43] V. Veleva, and M. Ellenbecker, "Indicators of sustainable production: framework and methodology", Journal of Cleaner Production, vol. 9, no. 6, pp. 519-549, 2001.

[44] I. S. Jawahir, K. E. Rouch, O. W. Dillon, Jr., L. Holloway, A. Hall, and J. Knuf, "Design for sustainability (DFS): new challenges in developing and implementing a curriculum for next generation design and manufacturing engineers", in Proceedings of $3^{\text {rd }}$ SME International Conference on Manufacturing Education 2005, San Luis Obispo, California, pp. 1-13.

[45] C. Labuschagne, A. C. Brent, and R. P. G. V. Erck, "Assessing the sustainability performances of industries", Journal of Cleaner Production, vol. 13, no. 4, pp. 373-385, 2005.

[46] R. K. Singh, H. R. Murty, S. K. Gupta, and A. K. Dikshit, "Development of composite sustainability performance index for steel industry", Ecological Indicators, vol. 7, no. 3, pp. 565-588, 2007.

[47] Q. Zhu, J. Sarkis, and K. H. Lai, "Green supply chain management: pressures, practices and performance within the Chinese automobile industry", Journal of Cleaner Production, vol. 15, no. 11/12, pp. 1041-1052, 2007.

[48] C. A. Rusinko, "Green manufacturing: an evaluation of environmentally sustainable manufacturing practices and their impact on competitive outcomes", IEEE Transactions on Engineering Management, vol. 54, no. 3, pp. 445-454, 2007.

[49] C. Reich-Weiser, A. Vijayaraghavan, and D. A. Dornfeld, "Metrics for sustainable manufacturing", in Proceedings of the 2008 International Manufacturing Science and Engineering Conference, Illinois, USA, pp. 1-9.

[50] W. Piotrowicz, and R. Cuthbertson, "Sustainability - a new dimension in information systems evaluation", Journal of Enterprise Information Management, vol. 22, no. 5, pp. 492-503, 2009.

[51] M. L. Tseng, L. Divinagracia, and R. Divinagracia, "Evaluating firm's sustainable production indicators in uncertainty", Computers \& Industrial Engineering, vol. 57, no. 4, pp. 1393-1403, 2009.

[52] M. Niskala, and H. Schadewitz, "Financial value measurement of corporate responsibility", in Proceedings of the Corporate Responsibility Research Conference 2009, University of Vaasa, Finland, pp. 349-373.

[53] N. D. Silva, I. S. Jawahir, O. Dillon, and M. Russell, “A new comprehensive methodology for the evaluation of product sustainability at the design and development stage of consumer electronic products", International Journal of Sustainable Manufacturing, vol. 1, no. 3, pp. 251-264, 2009.

[54] A. R. Hemdi, M. Z. M. Saman, and S. Sharif, "Sustainability evaluation for decision making", in Proceedings of the $11^{\text {th }}$ Asia Pacific Industrial Engineering and Management Systems Conference, APIEMS2010, Melaka, Malaysia, pp. 1-6.

[55] C. Fan, J. D. Carrell, and H. C. Zhang, "An investigation of indicators for measuring sustainable manufacturing", in Proceedings of IEEE International Symposium on Sustainable Systems and Technology 2010, Arlington, Virginia, pp. 1-5. 
This is a preview of SCOPUS.

Click here to learn more about accessing SCOPUS with our Integration Services. Visit also our SCOPUS Info Site.

The Scopus Author Identifier ass gns a unique number to groups of documents written by the same author via an algorithm that matches authorship based on a certain criteria. If a document cannot be confidently matched with an author identifier, it is grouped separately. In this case, you may see more than 1 entry for the same author

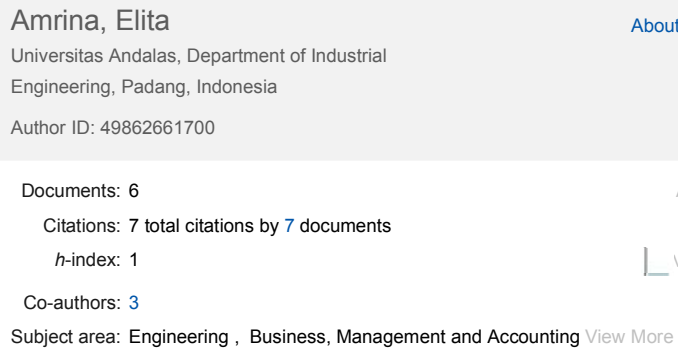

Export all | | Add all to list | | Set document alert

Set document feed

Key performance indicators for sustainable manufacturing Amrina, E.,Vilsi, A.L. 2015 Procedia CIRP evaluation in cement industry

Show abstract | Related documents

Key performance indicators for sustainable campus assessment: A case of Andalas university

\section{Amrina, E Imansuri, F 2015 Lecture Notes in} Electrical Engineering

Show abstract | Related documents

Interpretive structural model of key performance indicators Amrina, E., Vilsi, A.L. for sustainable manufacturing evaluation in cement industry

IEEE International Conference on Industria Engineering and Engineering Management

\section{Print | E-mail}

Show abstract | Related documents

Interpretive structural model of key performance indicators Amrina, E., Yusof, S.M. 20 for sustainable manufacturing evaluation in automotive companies

Show abstract | Related documents

Key performance indicators for sustainable manufacturing Amrina, E., Yusof, S.M. 2011 IEEE International evaluation in automotive companies

Show abstract | Related documents

\begin{tabular}{|c|c|c|c|}
\hline $\begin{array}{l}\text { Manufacturing performance evaluation tool for Malaysian } \\
\text { automotive small and medium-sized enterprises }\end{array}$ & Amrina, E.,Yusof, S.M. & 2010 & $\begin{array}{l}\text { International Journal of } \\
\text { Business and } \\
\text { Management Science }\end{array}$ \\
\hline
\end{tabular}

Show abstract | Related documents

\begin{tabular}{lll}
\hline Display $20 \quad \nabla$ results per page & Page 1 \\
\hline
\end{tabular}

The data displayed above is compiled exclusively from articles published in the Scopus database. To request corrections to any inaccuracies or provide any further feedback, please contact us (registration required). The data displayed above is subject to the privacy conditions contained in the privacy policy

$\begin{array}{lll}\text { About Scopus } & \text { Language } & \text { Customer Service } \\ \text { What is Scopus } & \text { 日本語に切り替える } & \text { Help and Contact }\end{array}$

Content coverage 切换到简体中文

Scopus Blog 切換到繁體中文

Scopus API

\section{$\Leftrightarrow$ Add to ORCID}

Request author detail corrections

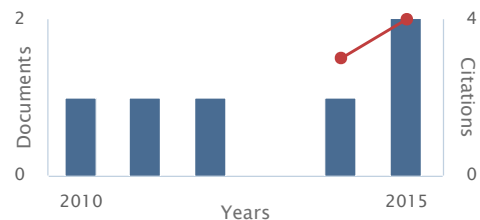

Documents $\rightarrow$ Citations

Author History

Publication range: 2010 - 2015 References: 94

Source history:

IEEE International Conference on Industrial Engineering and

Engineering Management

IEEE International Conference on Industrial Engineering and

Engineering Management

nternational Journal of Business and Management Science

View More

Shrov Related Affiliations
Engineering and

Engineering

Management

Conference on Industri

Engineering and

Engineering

切換到繁體中文 